\title{
Om forholdet mellem skabelse og syndefald hos Grundtvig og Luther
}

\section{Af Anja Stokholm}

"Når jeg ser din himmel, dine fingres værk, / månen og stjernerne, som du satte der, / hvad er da et menneske, at du husker på det, / et menneskebarn, at du tager dig af det?" Således synger den gammeltestamentlige digter i Salme 8 om skabelsens forunderlighed og formulerer dermed spørgsmålet om menneskets værd. Et svar på spørgsmålet følger i digterens videre lovprisning: "Du har gjort det kun lidt ringere end Gud, med herlighed og ære har du kronet det. Du har gjort det til hersker over dine hænders værk." Den bibelske skabelsestanke betragter mennesket som selve skabelsens højdepunkt. Mennesket er skabt kun lidt ringere end Gud. Det er skabt i Guds billede og efter hans lighed.

Denne bibelske tanke om menneskets gudbilledlighed videreføres som bekendt af både Luther og Grundtvig. Om menneskets skabelsesgivne særstilling kan der ikke herske tvivl. Hvad der i nærværende artikel skal tages op til unders $\varnothing$ gelse og overvejelse er derimod henholdsvis Luthers og Grundtvigs betragtninger om forholdet mellem denne skabelsesgivne særstilling og syndefaldet. Hvorledes må man med henholdsvis Luther og Grundtvig tale om dette skabte, men faldne menneskeliv? Hvad der skal undersøges, er altså spørgsmålet om det naturlige menneskes status og eksistensmuligheder set $\mathrm{i}$ lyset af både skabelsens positive aspekter og syndefaldets negative konsekvenser. Spørgsmålet er, hvordan skabelsen og syndefaldet forholder sig til hinanden.

Problemstillingen kan også formuleres som et spørgsmål om forståelsen af gudbilledlighedens status hos det naturlige menneske. Er gudbilledligheden tabt og dermed blot en mulighed, der først kan virkeligg $\varnothing$ res for det kristne menneske? Eller skal gudbilledligheden nærmere forstås som en - betinget - virkelighed allerede hos det naturlige menneske?

Hertil knytter sig spørgsmålet, om der for det naturlige menneske findes en forståelseshorisont for evangeliet og det kristne liv. Er det muligt for mennesket på baggrund af det naturlige liv at have en forståelse for evangeliets tale? Kan ideen om en sådan forståelseshorisont fastholdes, skal det yderligere klarlægges, om forudsætningerne for at forstå evangeliet blot har negativ karakter i form af syndserkendelse, eller om forudsætningerne også kan forstås positivt som en glimtvis erfaring af 
den sandhed, evangeliet henviser til. Luther og Grundtvigs tale om henholdsvis lov og evangelium og menneske forst, kristen så skal således inddrages.

Spørgsmålet, der skal stilles, er, om der inden for denne problemstilling er overensstemmelse mellem Luther og Grundtvig. Er Grundtvigs tænkning at betragte som en genuin overtagelse og videreførelse af det lutherske syn på det skabte, men dog faldne menneskeliv? Er det muligt på dette område at forene deres tænkning, eller findes der uoverensstemmelser mellem dem, der gør en egentlig sammentænkning af deres menneskesyn og kristendomsforståelser umulig? Er Grundtvigs tænkning i virkeligheden nærmere at betragte som et opgør med Luther?

\section{Regin Prenter. Et forsøg på sammentcenkning}

En kraftig understregning af sammenhæng mellem Luther og Grundtvigs tænkning finder man hos blandt andet Regin Prenter. Det afgørende argument for fastholdelsen af overensstemmelsen mellem Luther og Grundtvig findes ifølge Prenter i Grundtvigs videreførelse af Luthers reformatoriske hovedtanker med afvisning af menneskets egen fortjeneste, retfærdighed eller mulighed for frelse. ${ }^{1}$ Hovedsagen for Prenter er at fastholde, at Grundtvigs tale om den bevarede gudbilledlighed ikke fører til en ophævelse af Luthers tanke om den trælbundne vilje. Når Grundtvig derfor taler om det naturlige menneskes gudbilledlighed forstået som tro, håb og kærlighed, skal denne gudbilledlighed ifølge Prenter ikke forstås som

en religiøs-moralsk potens, som selv kan udfolde sig og dermed nærme sig Gud. Den er overhovedet ikke en menneskelig indsats, der vil kunne 'samarbejde' med Gud. Den er den forudsætning, som Gud i sin skabergerning selv sætter ind og opholder for sin genløsergerning. Den er derfor, set fra menneskets side, ikke noget aktivt, ingen ytring af den 'frie' vilje i luthersk forstand. ${ }^{2}$

Den afgørende forudsætning for med Grundtvig på samme tid at kunne fastholde talen om gudbilledlighedens bevarelse (der blandt andet ytrer sig i tro, håb og kærlighed) og tanken om sola fide er således understregningen af, at den gudbilledlige rest ikke er et resultat af menneskets egen præstation, men derimod et resultat af Guds opretholdelse af sit skaberværk.

Denne hos Grundtvig så centrale tanke om gudbilledets bevarelse tolkes af Prenter som det skabte menneskes forudsætning for at kunne 
tiltales af evangeliet. Indholdsbestemmelsen af gudbilledligheden er derfor if $\varnothing$ lge Prenter koncentreret om ordet, talens mulighed. ${ }^{3}$

Dermed er der ifølge Prenter påpeget endnu en overensstemmelse mellem Luther og Grundtvig. Der henvises således til en hos Luther lignende tanke om menneskets egnethed til at modtage evangeliet. Forudsætningen for at forstå evangeliets tale skulle således hos både Luther og Grundtvig bestå i en "også gennem faldet bevaret passiv bekvemhed hos mennesket til at høre Guds ord". ${ }^{4}$ Kun med skabelsen som forudsætning kan en sand tilegnelse af evangeliet finde sted.

En sådan sand evangelisk sammentænkning af skabelse og genløsning står ifølge Prenter centralt hos både Luther og Grundtvig. Med to forskellige udtryk vil de begge understrege skabelsestankens realitet trods syndefaldet. Prenter påpeger således, at der er sammenfald i tankegangen mellem Luthers tale om "lov og evangelium" og Grundtvigs tanke om "menneske først, kristen så". 5 Grundtvigs udsagn skal ifølge Prenter forstås helt i forlængelse af Luthers. At være "menneske først" bliver følgelig ensbetydende med at se sig forpligtet af lovens fordring med erkendelsen af, at en egentlig opfyldelse af loven er umulig. Samvittighedserfaringen af egen utilstrækkelighed over for loven og det i loven indeholdte domsord udgør således forudsætningen for syndserkendelsen og tilegnelsen af evangeliets syndsforladelse. ${ }^{6}$ Prenter kan udtrykke tankegangen på følgende måde: "I jaordet til dommen og i længselen efter genløsning er mennesket sandt menneske. Og kun når det er sandt menneske forst, bliver det kristen derefter." At være af sandhed eller at gøre sandheden er således if $\varnothing$ lge Prenter ensbetydende med at give loven ret i dens fordømmelse af mennesket. Overensstemmelsen mellem Luther og Grundtvig understreges yderligere med følgende udsagn:

At være sandt menneske er at dømme sin falske menneskelighed sådan, at den eneste mulighed for at leve er genløsningen. ' $\mathrm{Er}$ kristendom da sandheds sag, om kristen ej han er i dag, han bliver det i morgen' (...) Her kan rækkefølgen ikke byttes om. Loven må dømme først, evangeliet frikende derefter. Menneske først, kristen så. Det betyder: Guds fortabte skabning først. Derefter Guds genløste barn.,"

Med stor styrke understreges det af Prenter, at

Grundtvigs tanke ligger helt på linie med Luthers, når han lader lovens tid gå forud for nådens tid. Sandt menneske kan mennesket ikke gøre sig selv til. Men mennesket kan åbne sit $\emptyset$ re for sandheds ord og unde Gud sin ære, nemlig når Gud dømmer mennesket gennem 
sin skabelses lov. Det er at være menneske først. ${ }^{9}$

I en sådan bestemmelse af det skabte menneskeliv synes negativiteten at have forrang. Som forståelseshorisont for evangeliet er det menneskelivets negative aspekter, der fremhæves: menneskets magtesløshed over for lovens krav, lovens karakter af tvang til ydre overholdelse og Guds dom over det syndige og trælbundne menneske.

Prenter synes imidlertid også at ville fastholde en forestilling om det naturlige menneskelivs positive aspekter som forudsætning for at høre og tro evangeliets ord. Forestillingen om et sådant sandt naturligt menneskeliv udfolder Prenter i forlængelse af Grundtvigs tanker om Guds opretholdelse af sit skaberværk gennem ordet og ånden. Det er i denne sammenhæng, Grundtvigs tale om gudbilledlighedens bevarelse skal forstås. Som en rest af gudbilledligheden er menneskeordet og menneskeånden et resultat af skabelsens nåde, og således ikke udtryk for menneskets egen præstation, men derimod Guds opretholdelse af skaberværket. ${ }^{10}$ Netop på grundlag af denne skabelsens nåde er der mulighed for en eksistensform, der ligger nær skabelsens oprindelige sandhed. En eksistensform, der dog ikke er uantastet. Prenter formulerer det på den måde, at "Gud ikke kan opretholde menneskeliv, uden at det $\mathrm{i}$ nogen grad ligner, hvad det er bestemt til". " Konsekvensen af en sådan forståelse bliver, at mennesket, allerede på baggrund af sit naturlige liv, har positiv erfaring og forståelse for evangeliets tale. Udtrykt med Prenters ord:

Hvor mennesket ikke under Skaberens hånd i det folkelige vækkes til at se, hvad liv og sandhed er, og dermed længes efter det og længes efter befrielse fra synden og døden, der kan det ikke frivilligt tage imod befrieren, når han ydmygt kommer, klædt i modersmålets dragt." $" 12$

Prenters forståelse af det naturlige livs sandhedsbegreb er altså ikke entydig. Der tegner sig derimod to - måske modstridende - tendenser i fortolkningen af sandhedsbegrebet. På den ene side bestemmes sandhed som identisk med det skabte menneskes syndserkendelse og jaord til Guds dom over synderen. Hvad der her er i fokus er således tanken om den falske menneskelighed ${ }^{13}$ og synet på det naturlige menneske som en magtesløs og fortabt skabning. ${ }^{14}$ Denne negative bestemmelse af det skabte menneskeliv fremtræder hos Prenter som den væsentligste forståelse. Den ovenfor refererede betragtning af sandhedsbegrebet som en positiv eksistensmulighed allerede for det naturlige menneske spiller 
derimod en langt mindre rolle. Denne forskel kommer særlig tydelig frem i Skabelse og genlosning, hvor den positive bestemmelse af sandhedsbegrebet er begrænset til en kort passage i en ekskurs, ${ }^{15}$ mens tanken om syndserkendelsen og Guds dom over det falske menneskeliv står centralt i hele værket. Bemærkelsesværdigt er endvidere, at Prenter i 2. udgaven af Skabelse og genløsning har fjernet udsagnet om, at "Gud ikke kan opretholde menneskeliv, uden at det i nogen grad ligner, hvad det er bestemt til", ${ }^{16}$ hvilket yderligere understreger Prenters interesse $\mathrm{i}$ at betone syndsaspektet.

Det viser sig altså, at Prenters sammentænkning af Luther og Grundtvig lader Grundtvigs tænkning ligge helt i forlængelse af Luther. Grundtvig er ifølge Prenter en sand arvtager af en luthersk menneske- og kristendomsforståelse.

Flere spørgsmål trænger sig imidlertid på efter en gennemgang af Prenters forståelse af forholdet mellem Luther og Grundtvig. Først må der sættes spørgsmålstegn ved Prenters identifikation af Grundtvigs tanke om "menneske først, kristen så" med Luthers tale om lov - evangelium. Ved denne identifikation bestemmer Prenter Grundtvigs sandhedsbegreb negativt og forstår det som Guds dom over den falske menneskelighed. Spørgsmålet er imidlertid, om det er en retmæssig indholdsbestemmelse af Grundtvigs begreb "menneske først, kristen så?".

Som vist er dette imidlertid ikke den eneste måde, hvorpå Prenter bestemmer Grundtvigs begreb. Skønt nedtonet fastholdes også forståelsen af sandheden som en positiv eksistensform allerede i det skabte liv. Spørgsmålet rejser sig derfor, om Prenter her ikke modsiger sig selv? Kan begge aspekter af sandhedsbegrebet fastholdes samtidig, eller udelukker de to forståelser hinanden? Viser det sig, at en sammentænkning er mulig, må dog det spørgsmål stilles, om man med Prenter må insistere på den negative forståelses forrang frem for den positive.

Derudover må også det spørgsmål stilles, om Grundtvigs tanker om viljen ligger helt på linie med Luthers, eller om der hos Grundtvig findes afvigelser, der indebærer, at man ikke umiddelbart kan tale om en overtagelse af Luthers tanker om den trælbundne vilje? Kort sagt: er forskellen mellem Luther og Grundtvig i virkeligheden st $\varnothing$ rre end Prenter (og med ham store dele af den danske forskningstradition) vil være ved?

Et svar på ovennævnte spørgsmål kan kun udfærdiges ved en tilbagevenden til kilderne selv - det vil sige ved at undersøge Grundtvigs syn på det skabte, men faldne menneskeliv og sidestille det med det menneskesyn, som kommer til udtryk i Luthers tænkning. Det er netop fremgangsmåden for nærværende artikel. Først skal således Grundtvigs 
skabelsesforståelse, hans forståelse af syndefaldet og dets konsekvenser, samt synet på den efter syndefaldet fortsatte skabelse klarlægges. Efter en sådan undersøgelse kan en sidestilling med det lutherske menneskesyn foretages, og dermed et svar på ovennævnte problemstilling fors $\varnothing$ ges formuleret.

\section{Grundtvigs skabelsesforståelse}

Grundtvigs skabelsesforståelse er som nævnt koncentreret om menneskets særstilling. Bibelens tale om menneskets skabelse af st $\varnothing v$ og ånd i Guds billede afslører ifølge Grundtvig noget væsentligt om mennesket og dets eksistensvilkår.

Mennesket er ingen Abekat (...) men han er en mageløs, underfuld Skabning, i hvem Guddommelige Kræfter skal kundgiøre, udvikle og klare sig giennem tusinde Slægter, som et Guddommeligt Experiment, der viser, hvordan Aand og St $\varnothing v$ kan giennemtrænge hinanden, og forklares i en fælles guddommelig Bevidsthed. ${ }^{17}$

Sådan lyder Grundtvigs berømte tolkning af menneskets skabelse i Nordens Mythologi (1832). Som citatet antyder, består det underfulde i denne skabelse ifølge Grundtvig i foreningen af det himmelske og det jordiske, det åndelige og det legemlige eller blot: ånd og st $\varnothing \mathrm{v}$. Forklaringen på denne forening skal findes i Bibelens udsagn om menneskets skabelse i Guds billede. Det væsentligste aspekt ved menneskets gudbilledlighed er ifølge Grundtvig, at mennesket på underfuld måde er i slægt med Gud selv. Dette slægtskab træder særlig tydeligt frem i menneskets beherskelse af ordet, i talens mulighed - som af Grundtvig bestemmes som en genlyd af Guds eget ord. ${ }^{18}$ Med det mundtlige ord er der således if $ø$ lge Grundtvig forbundet en livskraft, som ikke er menneskets egen præstation, men som peger på en magt uden for mennesket selv. At menneske-ordet er at betragte som et genlydsord, er et tegn på, at Guds kraft er nærværende i ordet. Menneskets delagtighed i denne livskraft betyder, at det ikke kun er legemligt, men også åndeligt bestemt. Mennesket kan således betegnes som et åndsvæsen med mulighed for at erfare det åndelige og det usynlige, der hører Gud til.

Som det guddommelige ord rummer også menneske-ordet en vis grad af livskraft, sandhed og kærlighed. ${ }^{19}$ Allerede fra skabelsens side har mennesket altså fået del i disse ordets kendetegn. Som skabt i Guds billede har det erfaring for en eksistens i troens tillidsfuldhed, håbets rettethed og kærlighedens fællesskab. ${ }^{20}$ Som skabt ud af sandheds ædle 
stamme kan det fra sit eget liv kende sandhed fra løgn. ${ }^{21}$ Afgørende er, at disse menneskelige egenskaber ikke betragtes som menneskets egen præstation og dermed isoleres fra gudstanken. Grundtvig fastholder derimod, at der er tale om et lån fra Gud. ${ }^{22}$ Menneskets egenskaber er altså at betragte som en fra Gud delegeret gave, et udtryk for skabelsens nåde.

Som et sammenfattende begreb for disse tanker henviser Grundtvig til menneskets hjerte. Hjertet bliver dermed et udtryk for det specifikt menneskelige og kommer ofte til at fungere som et synonym for gudbilledligheden. ${ }^{23}$ Det er således i kraft af hjertet, at mennesket er i stand til at forstå og tage imod Guds ord. ${ }^{24}$ Grundtvig udtrykker det på denne måde: "Hjerterne [er] Guds Næster, Kun med dem Han taler selv!" ${ }^{25}$ Kun fordi Gud er hos mennesket med sin skabermagt - Guds ånd har forbundet sig mennesket - kan der i ordet ske et møde mellem Gud og mennesket.

Karakteristisk for Grundtvigs skabelsesforståelse er altså, at menneskets åndelige såvel som legemlige side understreges. Mennesket er - som skabt af støv og ånd - beviset på, at det legemlige og åndelige ikke er absolutte modsætninger. En bestemmelse af mennesket som muldets frænde ${ }^{26}$ eller jord-klimp ${ }^{27}$ hindrer derfor ikke, at mennesket samtidig kan være åndeligt bestemt.

\section{Grundtvigs forståelse af syndefaldet og dets konsekvenser}

Med syndefaldet er der imidlertid påført "Menneske-Livet i Guds Billede" en "Grund-Skade". ${ }^{28}$ Hvor langt denne grundskade - det vil sige syndigheden - strækker sig, kan mennesket ifølge Grundtvig aldrig komme til fuld erkendelse af. Hvad der derimod kan fastslås er, at skaden, synden, er så stor, "at den i det hele kun lader sig helbrede ved Guds Søns Fornedrelse og Opofrelse, og selv af Guds Søn kun lader sig helbrede med en virkelig Gienfødelse og Nyskabelse". ${ }^{29}$ Grundtvig understreger faldets og syndens alvor.

Årsagen til faldet er at finde i menneskets manglende tro på Guds ord. Hvor der før herskede tro og tillid, er tvivlen nu fremherskende. I stedet for at lade sig tiltale af Guds ord har mennesket sat sig selv i Guds sted. Egenmægtigt vil Adam - mennesket - tage det liv, der kommer fra Gud, i egne hænder. Synden består til enhver tid i menneskets selvrådighed og selvtilstrækkelighed. ${ }^{30}$ Grundtvig understreger heroverfor, at i sig selv er mennesket intet. Om mennesket efter syndefaldet siges der: "Ser jeg ind $i$ Hjertekamret / Og i Hjerneskrinet mit / Overalt jeg sporer Døden, / Ser og 
mere Sort end Hvidt." ${ }^{, 31}$ Menneskets hjerte er forstenet - kun en nyskabelse kan forandre det. ${ }^{32}$ Tankegangen udtrykkes tydeligst med følgende ord: "I os selv er intet Godt / Men kun Ondt, desværre, / Thi der er slet intet Godt, / Udenfor Vorherre. ${ }^{, 33}$ I det naturlige menneske er det synden og døden, der hersker.

Døden betragtes af Grundtvig som den alvorligste side af syndefaldet - i sine mange skikkelser er den menneskets arvefjende. ${ }^{34}$ Bag døden står ifølge Grundtvig en personlig ond magt. Menneskets egentlige fjende er Djævlen. Grundtvig siger om Djævlen, at han er: "Menneske-Morderen af Begyndelsen (...) han er Løgnens Fader, (...) lige saavel Menneskets som Sandhedens arrige Fjende." 35 Denne ihærdige understregning af Djævlen som en personlig ødelæggelsesmagt - en ontologisk størrelse, der præger menneskets tilværelse - er hos Grundtvig i særlig grad vendt mod samtidens monistiske tendenser.

Med denne fastholdelse af Djævlen som en virkelig og personlig magt kommer dualismen til at spille en afgørende rolle i Grundtvigs tænkning. Mennesket befinder sig midt imellem Gud og Djævel - mellem skaberen og løgneren. Det er løgnen - det vil sige Djævlen, bagtaleren - der er syndens rod. ${ }^{36}$ Djæulen er fristeren, der bedrager mennesket ved at omvurdere alle værdier. ${ }^{37}$ Grundtvig forstår således syndefaldet som Djævlens forførelse af mennesket.

Samtidig med denne kraftige understregning af Djævlens magt og syndens alvor spiller dog tanken om en delvis opretholdelse af den oprindelige skabelsestilstand en afgørende rolle i Grundtvigs tænkning. Tydeligst kommer tanken frem i Grundtvigs understregning af, at der også efter syndefaldet findes en rest af gudbilledligheden hos mennesket - en tanke, som Grundtvig udfolder i direkte polemik mod en syndsforståelse, der i sin iver for at understrege syndefaldets alvor og genløsningens kraft forstår gudbilledligheden som fuldstændig udslettet og menneskelivets oprindelige godhed som helt tilintetgjort. ${ }^{38}$ Grundtvig retter en voldsom kritik mod en syndsforståelse, der ved at gøre syndigheden større vil understrege genløsningens herlighed - og derved må betragte mennesket som "et blot Dyr, eller dog et U-Menneske". ${ }^{39}$ En sådan forestilling er ifølge Grundtvig teologisk uholdbar. Grundtvig skriver: "Hele den saakaldte Bibel-Historie kan (...) kun være sand under den Forudsætning, at Menneske-Livet, før og efter Syndefaldet og før og efter Gienfødelsen, er aldeles eensartet og igrunden det selv samme." ${ }^{40}$ Skabelsen i Guds billede er en forudsætning for at genløsningen kan ske, thi

dersom Mennesket ikke var skabt i Guds Billede (...) da var det 
umuligt for Mennesket at have nogen sand og levende Forestilling om Gud eller hans Egenskaber, hvortil Mennesket kun er bekvemt, naar der er Noget i Mennesket af Alt hvad der er $i$ Gud. ${ }^{41}$

Netop fordi der er en rest tilbage af Guds gode skaberværk i mennesket, kan det forstå Guds henvendelse og føle sig tiltalt af hans ord. Mennesket er også efter syndefaldet et åndsvæsen, der har mulighed for både at udtrykke og have erfaring for en åndelig og evig sandhed. ${ }^{42}$

Grundtvig udtrykker også tankegangen på den måde, at en menneskelig mulighed for "Godvillighed" må forudsættes, hvis genfødselen skal kunne finde sted. ${ }^{43}$ Til belysning af tankegangen henviser Grundtvig til skriftens fortælling om den fortabte $s ø n$ og understreger samtidig, at talen om godvilligheden ikke er ensbetydende med en tilbagevenden til gerningsretfærdighed. ${ }^{\text {H4 }}$ Hvad Grundtvig vil gøre klart, er således, at forestillingen om en delvis bevarelse af menneskelivets oprindelige godhed og herlighed kan og skal fastholdes samtidig med tanken om frelse ved troen alene. Troen, håbet og kærligheden er trods syndefaldet og syndens virkelighed stadig en realitet $\mathrm{i}$ det naturlige menneskeliv, hvilket blandt andet kommer til udtryk i forholdet mellem forældre og børn og mellem mand og kvinde. ${ }^{45}$ Grundtvig skriver:

saaledes fulgde ogsaa en Levning af Troen, af Haabet og af Kiærligheden det faldne Menneske ud af Paradiis og ind i Ørken, hvor de vistnok alle, med Afmagten og det dødelige Saar, som var Syndens Handsel, rimeligviis snart maatte uddøe, men kunde dog mueligviis ogsaa af Guds Naade vidunderlig opholdes og styrkes, og i Tidens Fylde af samme Guds Naade i hele sin Rigdoms Aabenbarelse gienfødes og fornyes efter Hans Billede, som skabte os. ${ }^{46}$

Grundlæggende for hele Grundtvigs tænkning er hans skelnen mellem Guds nåde i skabelsen og nåden i frelsen. Når det skabte menneske fra sit eget naturlige liv har erfaring for kærlighed og sandhed, er det et udtryk for, at skabelsens kraft - trods syndefaldet - sætter sig igennem. Gud har ved sin nåde opretholdt en mulighed for en sand eksistensform, en eksistensform, der dog på grund af synden ikke er uantastet. Derfor må Grundtvig, når han har sagt: "I os selv er intet Godt," fortsætte: "Hos os dog en Smule. ${ }^{, 47}$ I sig selv er mennesket intet. Isoleret set hersker kun synden $\mathrm{i}$ mennesket. Men $\mathrm{i}$ kraft af skabelsens nåde er der "Noget $\mathrm{i}$ Mennesket af Alt hvad der er i Gud" ${ }^{48}$ Grundtvig formulerer tanken kort og præcist således: "Alt Guds Laan, trods Synd og Død, / Leve skal og lykkes. ${ }^{, 49}$ Tanken om en naturlig godhed og sandhed er ikke et udtryk for 
en menneskelig præstation, men er netop et lån, en gave - et udtryk for Guds nåde.

Understregningen af skabelsens nåde betyder ikke, at nåden $\mathrm{i}$ frelsesspørgsmålet bliver overflødiggjort. Mennesket har fortsat behov for Kristi genløsende værk - intet menneske kan ved egen kraft overvinde synden. Denne dobbelthed i Grundtvigs tænkning bliver særlig tydelig i hans opg $\emptyset r$ med sine modstandere. På to fronter kæmper Grundtvig for en sand evangelisk kristendomsforståelse. Mod den kristendomsforståelse, der ved sin ivrige betoning af menneskets syndighed ifølge Grundtvig reducerer mennesket til et dyr eller en djævel, fremhæver han, at der er sammenhæng mellem det skabte, men faldne menneskeliv og det genløste menneskeliv. Der er i frelsen netop tale om en gen-løsning og en genfødsel - en delvis bevarelse af skabelsens oprindelige sandhed er ifølge Grundtvig den nødvendige forudsætning for inkarnationen og for at mennesket kan frelses. Frelsens nåde forudsætter skabelsens nåde. Denne tanke betyder imidlertid ikke, at Grundtvig nedskriver syndefaldets alvor, hvilket særligt tydeligt viser sig i hans opgør med den naturalistiske udlægning af syndefaldet og frelsen. Grundtvigs uenighed med naturalisterne gælder spørgsmålet om, hvordan syndefaldets ødelæggelse overvindes. Grundtvig skriver i Nordens Mythologi: "Sagen er kun, om Skaden kan helbredes paa naturlig Maade eller ikke, og (...) her er ingen Middel-Vej. ${ }^{50}$ Grundtvig understreger sagens alvor - der er tale om et enten-eller. Mens naturalisterne vil hævde, at mennesket ved egen kraft kan helbredes fra synden, må en sand evangelisk forståelse fastholde, "at Menneske-Naturen ved Faldet er blevet saa fordærvet, at al egenlig Helbredelse er umuelig" hvorfor man må "prise Daaben som et virkeligt Gienfodelsens Bad." ${ }^{51}$ Det bliver således tydeligt, at Grundtvigs tanker om menneskelivets iboende godhed ikke betyder en svækkelse eller banalisering af syndefaldets alvor. Dåben, som selve nerven i Grundtvigs kristendomsforståelse, understreger en sådan tolkning. Godheden og synden må fastholdes på samme tid.

Det er denne dualisme mellem godheden og synden, der efter syndefaldet bestemmer menneskets eksistens. I egentlig forstand er dualismen et udtryk for den kamp mellem Gud og Djævel, mellem liv og død, som mennesket befinder sig midt $\mathrm{i}$, og som gælder for alle tilværelsens områder. Der er tale om en uforsonlig kamp, en åndelig strid, som kun kan komme til ophør med den ene parts undergang. Liv og død er uforenelige modsætninger. Det er Gud og Djævel, der som tilværelsens to grundmagter står over for hinanden. Hvad der hører til hos Gud, kan aldrig forenes med, hvad der hører til hos Djævlen. Sandhed er uforenelig 
med løgn, lys med mørke, godt med ondt - liv er uforeneligt med død. Denne "Modsigelsens Grundsætning" eller "Sandhedens Grundlov", 52 som Grundtvig kalder den, er det grundvilkår, der bestemmer ethvert menneskes eksistens.

Det er på baggrund af denne stærke understregning af adskillelsen mellem Gud og Djævel, at Grundtvig afviser tanken om, at mennesket ved syndefaldet skulle være blevet så fremmed for Gud, at det kommer til at høre til hos Djævlen. Mennesket hører oprindelig til hos Gud, det er skabt af Gud, og også efter syndefaldet har det en rest af noget guddommeligt hos sig. Selv om mennesket er antastet af og delvis i Djævlens vold, kan det derfor aldrig i egentlig forstand høre til hos dets skabers modstander. Som Gud må også mennesket have Djævlen til fjende. ${ }^{53}$

\section{Grundtvigs forståelse af den fortsatte skabelse}

Menneskets dobbelte situation må altså ifølge Grundtvig fastholdes: både synden og skabelsens herlighed er virkeligheder i det naturlige menneske. Spørgsmålet er nu, hvordan Grundtvig forestiller sig, at denne bevarelse af den oprindelige skabelse kommer til udtryk i menneskelivet? Hvori består den gudbilledlige rest?

Det er som allerede omtalt blandt andet troen, håbet og kærligheden, der ifølge Grundtvig er vidnesbyrd om en bevarelse af den oprindelige skabelse. Grundtvig skriver: “'Tro, Haab og Kiærlighed' udtrykker hele den menneskelige indvortes Billedlighed med Gud. ${ }^{54}$ Det er afgørende at bemærke sig, at Grundtvig her bestemmer gudbilledligheden i form af tro, håb og kærlighed som indvortes. Når Grundtvig derfor et andet sted siger: "I os selv er intet Godt, Hos os dog en smule," skal dette udsagn ikke forstås således, at det, der er hos mennesket, kun er noget ydre. Når troen, håbet og kærligheden bestemmes som indvortes, betyder det, at det er i hjertet, menneskets lighed med dets skaber er funderet. Trods synden har mennesket stadig "Hjertet paa det rette Sted". 55 Det er tillige den forståelse, der er baggrunden for Grundtvigs allerede citerede udsagn om, at der er "Noget i Mennesket af Alt hvad der er i Gud". ${ }^{56}$ Der er således tale om en virkelig tro og en virkelig kærlighed, som gør sig gældende i både en ydre og en indre sammenhæng. I Danskeren 1851 siger Grundtvig således i en tale om danskerne:

vi er Mennesker, og har, som Mennesker, baade Liv og Lys i Sandhed og Kærlighed, som vel er snarere for lidt end for meget, men er dog af alt virkeligt det virkeligste, og af alt godt det bedste, vi kiender, saa vi 
maae nødvendig troe, at det lille Sandheds-Lys, der aabenbarer det lille Kærligheds-Liv, naar vi ærlig bekiender hvad der rører sig inden i os, det har sin Grund i et stort Sandheds-Lys, der aabenbarer et stærkt Kiærligheds-Liv. ${ }^{57}$

Med sin grund i Gud må menneskets kærlighed være et udtryk for noget oprigtigt og sandt. Kærligheden er mere end blot en følelse i hjertet, den er Guds fortsatte virke i mennesket. Gud selv er kærligheden (1 Joh $4,8) .{ }^{58}$

Det sted, hvor denne side af den guddommelige rest på tydeligste måde kommer til udtryk i menneskelivet, er ifølge Grundtvig i ægteskabet, i den naturlige kærlighed mellem mand og kvinde og i kærlighedsforholdet mellem forældre og børn og mellem søskende indbyrdes. Grundtvig skriver således:

baade var Ægteskabs-Forholdet fra Begyndelsen Menneske-Kiærlighedens Vugge, og maa i det gienfødte Menneskeliv ligefuldt være det, da al Kiærlighed til Næsten nødvendig maa begynde med Kiærlighed til den Allernærmeste. ${ }^{59}$

Den naturlige kærlighed, i særlig grad den kærlighed, der eksisterer inden for familiens rammer, er altså ifølge Grundtvig grundlaget for al anden kærlighed.

Troen, håbet og kærligheden må Grundtvig derfor fastholde som noget alment menneskeligt. Både det faldne og det genløste menneske har erfaring for en eksistens i troens tillidsfuldhed, håbets rettethed og kærlighedens fællesskab. ${ }^{60}$ Om disse tre siger Grundtvig således, at de er "langt fra at være noget Splinternyt, der først blev til med Christendommen", men at de "tvertimod er saa gamle som Menneskeslægten." 61

Som tidligere nævnt er det ikke alene troen, håbet og kærligheden, Grundtvig henviser til, når talen er om den gudbilledlige rest. Det tydeligste tegn på, at mennesket trods syndefaldet ikke er blevet fuldstændig væsensfremmed for sin skaber, findes ifølge Grundtvig i den kendsgerning, at mennesket stadig har "Aands-Ordet i sin Mund". ${ }^{62}$ Også i ordet har mennesket beholdt en kendelig lighed med Gud. Ordet er for Grundtvig netop det åndelige livs udtryk. Med det talte levende ord er der således bevaret et bånd mellem det himmelske og det jordiske, mellem Gud og menneske - et bånd, som er opretholdt af Gud selv.

Skal ordet ikke reduceres til at være et tomt og blot lydeligt udtryk, må det imidlertid forudsættes, at der i menneskets indre er noget, der svarer til det ydre talte ord. Grundtvig understreger derfor sammenhængen 
mellem ordet og hjertet. At mennesket også efter syndefaldet ifølge Grundtvig har "Hjertet paa det rette Sted"63 er allerede blevet beskrevet. Hermed har Grundtvig udtrykt, at den rest af menneskets lighed med skaberen, der på trods af syndens ødelæggelse er bevaret, er funderet i menneskets inderste - det vil sige er en del af det egentligt menneskelige. Derfor kan der være overensstemmelse mellem det hjertet føler og det ordet udtrykker - og omvendt. Ordet er ikke blot tomme lyde, men det er "Aandens Spejl og Hjertets Sprog". ${ }^{64}$

Med sammentænkningen af ordet og hjertet er der i Grundtvigs tænkning sat lighedstegn mellem eksistensen bestemt af tro, håb og kærlighed og ordets virkelighed. Både triaden og det talte ord er et udtryk for skabelsens bevarelse og ligheden med Gud, og således forudsætter de hinanden. Når Grundtvig bestemmer ordets indhold, sker det derfor helt $\mathrm{i}$ forlængelse af, hvad han siger om den almenmenneskelige triade. Hvad der kendetegner menneske-talen er således en større eller mindre grad af kraft, sandhed og kærlighed. Uden et vist indhold af disse egenskaber måtte talen betegnes som $\mathrm{d} \varnothing \mathrm{d}$, tom, falsk, hjerteløs - i egentlig forstand umenneskelig. ${ }^{65}$

Det står således fast, at det naturlige menneske i kraft af skaberens fortsatte bevarelse af gudbilledligheden har fået skænket muligheden for en eksistens bestemt af både sandhed, kærlighed og godhed. Mennesket har således glimtvis erfaring for en eksistens, hvor sandhed er skilt fra løgn, godhed fra ondskab og kærlighed fra had. En fornemmelse for livets uforenelige modsætninger findes allerede på det skabte naturlige plan. Det er for Grundtvig selve forudsætningen for, at genløsningen kan finde sted. Var ingen rest af menneskets skabelsesgivne herlighed bevaret, var mennesket fuldstændig berøvet muligheden for at opleve kærlighedens livsfuldbyrdelse, ordets, frihedens og sandhedens kraft, men havde det kun erfaring for en eksistens i selviskhedens og selvtilstrækkelighedens ufrie skikkelse, da havde det ingen forudsætninger for at forstå, røres af eller modtage evangeliets forjættelse. For Grundtvig udgør det naturlige skabte menneskeliv den nødvendige forståelseshorisont for evangeliets tale. Helt tydeligt siges det med disse ord af Grundtvig:

Hvor længe det nemlig end har været overset, og hvor dristig man endnu tit benægter det, saa er det dog lige klart og lige vist, at det gamle Menneskes Tro, Haab og Kiærlighed maa være eensartede med det ny Menneskes, da det ellers var umuligt, at det gamle Menneske kunde ved nogen som helst Aabenbaring faa en rigtig Forestilling om det ny Menneskes Tro, Haab og Kiærlighed, som han dog nødvendig 
maa have for at eftertragte dem og for at gienkende dem hos sig, og at derfor maa Kiærligheden mellem Forældre og Børn og den ægteskabelige Kiærlighed mellem Mand og Kvinde i det gamle Menneske-Liv, for saavidt den findes og saavidt den gaaer, være aldeles eensartet med Kiærligheden mellem den himmelske Fader og hans himmelske Børn, og med den ægteskabelige Kiærlighed mellem Christus og hans Menighed i det ny Menneskeliv. ${ }^{66}$

Ikke blot er der i det naturlige menneskeliv givet forhold og eksistensmuligheder, der ligner de himmelske og guddommelige forhold, men Grundtvig går så vidt som til at hævde, at hvor den naturlige kærlighed på jorden råder, er der tale om egentlig identitet med kærligheden, der udgår fra Gud selv. Kærligheden mellem mennesker er af Guds egen kærlighed. En højere lovprisning af den naturlige kærlighed kan ikke tænkes. Det er på den baggrund, Grundtvigs tale om det naturlige liv som forståelseshorisont for evangeliet skal forstås. I kraft af menneskelige erfaringer om kærlighedens livsfuldbyrdelse kan mennesket forstå, røres og glædes over evangeliets forjættelse om den kærlighed, der ikke er truet af nedbrydelse og ødelæggelse. Fordi vi kender den menneskelige betydning af ordene far, mor, barn, bror og søster, kan vi forstå, hvilken betydning det har, at Gud er vor far og vi hans børn. ${ }^{67}$ Ved at bevare kærlighedens mulighed blandt mennesker har Gud selv opretholdt forudsætningen for, at genløsningen kan finde sted.

Skal Grundtvig på sammenfattende vis give en karakteristik af det fra skabelsen bevarede menneskeliv, sker det med udsagnet om, at mennesket er "Af Sandheds ædle Stamme". 68 Også det naturlige menneske har "Glimt af Aand og Gnist af Sandheds-Kiærlighed". ${ }^{69}$ Det er denne bestemmelse af det naturlige menneskeliv med understregningen af ordets kraft, troens, håbets og kærlighedens virkelighed samt fastholdelsen af menneskets sandhedsbevidsthed, der er baggrunden for Grundtvigs berømte udsagn: "Menneske først og Christen saa." naturlige menneskeliv må på positiv måde udgøre forståelseshorisonten for kristendommen. Kun den, der er af sandhed, kan høre Guds ord. ${ }^{71}$ Skal mennesket kunne modtage kristendommen på sand vis, må det først være sandt menneske, det vil sige have erfaring for skabelsens sandhed som den - under en konstant trussel om nedbrydelse - kommer til udfoldelse i det naturlige menneskeliv. ${ }^{72}$ Har mennesket denne erfaring, da har det også en naturlig længsel efter at høre sandhedens - det vil sige. evangeliets -ord. Det er sådanne tanker og den heraf følgende protest mod samtidens overfladiske og ufrie missionspraksis, der får Grundtvig 
til at digte Menneske forst og Christen saa. K. E. Bugge har i artiklen 'Menneske først - Grundtvig og hedningemissionen' (se note 73) redegjort for baggrunden for og tilblivelsen af Grundtvigs digt. Bugge anfører her, at Grundtvigs digt med stor sandsynlighed er et svar til et andagtsstykke med overskriften Intet Menneske, ingen Christen forfattet af den tyske præst Heinrich Müller. ${ }^{73}$ Müller påpeger her nødvendigheden af at være menneske, førend man kan blive kristen. Det er sondringen mellem det gamle og det nye menneske, der optager Müller. Det gamle menneske bestemmer Müller nu som et umenneske og en synder. Skal mennesket blive et sandt menneske, en kristen, må det først erkende sig selv som umenneske og synder. Heraf udtrykket: "Intet Menneske, ingen Christen." Skønt Grundtvigs udtryk: "Menneske først og Christen saa" i ordlyd ligger helt i forlængelse af Müllers, må Grundtvigs digt $\mathrm{i}$ et helhedsperspektiv betragtes som et opgør med Müllers forståelse. Bugge skriver:

Mens for Müller det egentlige menneskelige bestod i syndsbevidstheden, var det for Grundtvig de positive menneskelige egenskaber, der var afgørende, f.eks. 'Glimt af Aand og Gnist af SandhedsKiærlighed', samt villigheden til at åbne sit $\emptyset$ re for 'Sandheds Ord'. ${ }^{74}$

Det er afvisningen af "miskendelsen af mennesket og det egentligt menneskelige", ${ }^{75}$ der er baggrunden for Grundtvigs digt Menneske forst og Christen saa. Som forståelseshorisont for evangeliet må menneskelivets positive frem for dets negative sider fremhæves.

Det er altså i en vis forstand den lutherske forestilling om lovens teologiske brug, det vil sige forestillingen om, at det er loven, der bringer mennesket syndserkendelse og dermed fungerer som "tugtemester" til Kristus og som forståelseshorisont for evangeliet, Grundtvig retter en indvending imod. Interessant er det således at unders $\varnothing \mathrm{ge}$, hvad Grundtvig på mere direkte måde siger om sin forståelse af loven og om dens forhold til evangeliet.

I artiklen 'Moses og Jesus' fra Dansk Kirketidende (1852) udfolder Grundtvig sin forståelse heraf. Grundtvig påpeger, at skønt Luther er nået langt i forståelsen af forholdet mellem loven og evangeliet, så har han alligevel ikke formået at løse "Haardeknuden". ${ }^{76}$ Ved at fastholde de ti bud som en del af den kristelige børnelærdom har Luther ifølge Grundtvig selv gjort sig skyldig i en sammenblanding af loven og evangeliet. Intet bud, end ikke det dobbelte kærlighedsbud, kan stilles i spidsen for den kristelige børnelærdom. I stedet for må der som undervisning og forberedelse for kristendommen henvises til dåben og 
trosbekendelsen, som lyder her. Og i dåben er det netop ikke "Lovkyndighed og endnu mindre nogen Slags Retfærdiggiørelse af Loven, men kun, hvad der fra først til sidst er Sjælen i hans [Kristi] egen Lærdom, nemlig Omvendelse og Tro", ${ }^{77}$ som er i centrum. Omvendelsen kommer ifølge Grundtvig til udtryk som forsagelsen af Djæulen. Forsagelsen og trosbekendelsen er netop ifølge Grundtvig dåbspagtens to uadskillelige dele. ${ }^{78}$ Det er modsigelsens grundsætning eller sandhedens grundlov, det vil sige den uforsonlige kamp mellem Gud og Djævel, mellem liv og død, mellem sandhed og løgn og mellem lys og mørke, som kommer til udtryk i dåbspagtens to dele. Grundtvig fastholder, at det er bevidstheden om denne strid - i langt højere grad end kendskab til lovens bud - som er den nødvendige forudsætning for at forstå evangeliet.

Alligevel kan også Grundtvig tale om loven som en forberedelse til kristendommen. Det særlige ved Grundtvigs syn på loven er dog, at han $\mathrm{i}$ stedet for at tale om loven som en tugtemester til Kristus taler om "Moses som 'Skolemesteren' for al Verden, som fører hvem der ønsker det til Jesus". ${ }^{79}$ Også i synet på loven står Grundtvigs tanke om friheden centralt: loven betragtes som en "Oplysning som man frit benytter sig af, som man kan og vil". ${ }^{80}$ I den grundtvigske forståelse bliver loven således et middel til folkeopdragelse. Lovens opgave er at gøre ethvert folk "velberedt til Christendommens Velsignelse". ${ }^{81}$ Således er loven at betragte som en "menneskelig Børnelærdom (...) en aandelig og hjertelig Forberedelse". ${ }^{82}$ Det interessante er nu, at Grundtvig, når han taler om en sådan forberedelse, henviser til skabelsesberetningen fra Første Mosebog. Den nødvendige forudforståelse for evangeliet må findes $\mathrm{i}$

en tydelig Forestilling om den sande Gud, som Himmelens og Jordens Skaber, om Skabelsen ved Ordet, som den sikkre Almagts-Gierning, der maa være vor Maalestok for alt hvad der kalder sig guddommelige Tegn og Vidunder, og da især om Menneskets Skabelse efter Guds Billede og Lignelse, med Paradis og Syndefald; thi først ved denne Oplysning af første Mosebog tændes der et Lys i vor Tankegang om det oprindelige Forhold mellem Gud og Menneske og om det syndige Menneskes Trang til en guddommelig Frelser. ${ }^{83}$

Grundtvigs tale om loven skal altså forstås i meget bred forstand: loven inkluderer hele skabelsen. Denne tendens viser sig også ved, at Grundtvig hellere end "loven" bruger udtrykket "Moses og Profeterne". Det er skabelsen frem for loven forstået som forbud og påbud, der vidner om forholdet mellem Gud og menneske og om menneskets livsvilkår. Loven 
er skabelsens lov, som giver kundskab om det skabte livs dobbelthed: den bevarede gudbilledlige herlighed og menneskets nedbrydelse af denne herlighed. Det må imidlertid påpeges, at det også i denne tekst er menneskelivets positive fænomener, Grundtvig hæfter sig ved. Tankegangen i artiklen 'Moses og Jesus' ligger således helt i forlængelse af det, Grundtvig udfolder i digtet Menneske forst og Christen saa. Det er erfaringen af skabelsens sandhed, der er den primære kilde til forståelse for evangeliets tale.

\section{Overensstemmelse mellem Grundtvig og Luther?}

Det afgørende spørgsmål er nu, om der er sammenfald mellem den grundtvigske forståelse af forholdet mellem skabelsen og syndefaldet og Luthers forståelse heraf. Er det korrekt, med blandt andet Prenter, at fastholde sammenhængen og identiteten mellem Grundtvigs og Luthers tænkning? Prenter vil som anført i indledningen understrege, at både Luther og Grundtvig afviser tanken om menneskets egen fortjeneste eller mulighed for frelse. Også hos Grundtvig findes ifølge Prenter tanken om viljens trælbundethed. Det er denne understregning af overensstemmelse, der får Prenter til at sætte lighedstegn mellem Luthers tanke om "lov og evangelium" og Grundtvigs forestilling om "menneske først, kristen så". Ifølge Prenter giver begge udsagn udtryk for et ret forhold mellem skabelse og genløsning. Afgørende er nu, at Prenter tolker Grundtvigs udsagn "menneske først, kristen så" ved hjælp af lutherske termer. Som beskrevet $\mathrm{i}$ indledningen bliver Grundtvigs forståelse af det at være "menneske først" ensbetydende med erkendelsen af egen utilstrækkelighed og magtesløshed. Kun som sandt menneske, det vil sige kun med bevidstheden om at være fortabt under Guds dømmende lov, kan den enkelte tilegne sig evangeliet. Forudsætningen for evangeliets modtagelse bliver således af negativ karakter: nemlig i form af syndserkendelse og tilslutning til Guds dom over den falske menneskelighed.

At det næppe er sådanne tanker, Grundtvig vil udtrykke med formuleringen "menneske først, kristen så", skulle være fremgået med tydelighed af artiklens tidligere afsnit. Med ihærdighed understreger Grundtvig, at det er på baggrund af menneskelivets positive sider, at evangeliets forjættelse bliver meningsfuld: for at skønne på Guds kærlighed må mennesket have kendskab til kærlighedens mulighed allerede fra sit eget naturlige liv, for at have tillid til Gud Fader må den enkelte have menneskelige erfaringer for tillids- og kærlighedsforholdet mellem forældre og børn - kort sagt, mennesket må have erfaring for "de 
aandelige Grund-Ord 'Sandhed', 'Samvittighed', 'Frihed' og 'Kiærlighed'." ${ }^{84}$ Skal mennesket have mulighed for at forstå og tilegne sig evangeliets tale, må det først have erfaring for, hvad sådanne ord betyder i en ren menneskelig sammenhæng. Det er på den baggrund Grundtvigs udtryk "menneske først, kristen så" skal forstås. At være sandt menneske bliver således i en grundtvigsk forståelse netop ensbetydende med at lade sådanne positive forhold være bestemmende for eksistensen. Muligheden herfor har mennesket, fordi det er "af Sandheds ædle Stamme" mennesket har også efter syndefaldet del i skabelsens oprindelige sandhed. Eller med et andet grundtvigsk udtryk: også det naturlige menneske er af ånd - hvilket for Grundtvig vil sige, at mennesket har del i Guds ånd. Mennesket har bevaret en kendelig lighed med sin skaber. En lighed, som Gud selv i kraft af sin fortsatte skabelse opretholder i mennesket. Det er tanken om menneskets bevarede gudbilledlighed, der ligger bag Grundtvigs udsagn "menneske først, kristen så" og bag forestillingen om den sande menneskelighed. Ved sin skaberkrafts nåde skænker Gud mennesket de positive eksistensmuligheder, som er forudsætningen for at genløsningen kan finde sted.

At det ikke er syndserkendelsen og bevidstheden om den falske menneskelighed, der for Grundtvig er den primære kilde til forståelse af evangeliets forjættelse, bliver bekræftet af Bugges artikel om baggrunden for og tilblivelsen af Grundtvigs digt Menneske forst og Christen saa. Er Grundtvigs digt et resultat af et opgør med den tyske præst Müller og den kristendomsforståelse, han repræsenterer, så har Grundtvig jo i virkeligheden selv med udtrykket

'menneske først, kristen så' afvist den forståelse, som Prenter tillægger ham. Det egentlige menneskelige er for Grundtvig ikke syndserkendelsen, men 'først og fremmest menneskets Gud-givne positive egenskaber'. ${ }^{86}$

At man ikke umiddelbart kan sætte lighedstegn mellem Luthers "lovevangelium"-tanke og Grundtvigs forestilling om "menneske først, kristen så", bliver yderligere bekræftet af Grundtvigs bestemmelse af lovens rolle i artiklen 'Moses og Jesus'. Artiklen er på flere måder et vidnesbyrd om den forskydning, der findes mellem Luthers og Grundtvigs kristendomsforståelser. For det første bliver det her tydeligt, hvordan Grundtvig betoner modsætningen mellem liv og død, det vil sige mellem Gud og Djævel, frem for modsætningen mellem lov og evangelium. Det er erfaringen af striden mellem tilværelsens to grundmagter mere end lovens synds- og domsforkyndelse, der er den nødvendige 
baggrund for at tilegne sig evangeliet. Grundtvig forudsætter et almentmenneskeligt kendskab til både livets og dødens fænomener. Således må dåbens forsagelse af Djævlen og bekendelse til Gud stadfæstes som den sande og egentlige børnelærdom frem for lov evangelium problematikken. Det er i dåbens sakramente, at uforeneligheden mellem liv og død - mellem Gud og Djævel - bliver tydeligst.

Også på anden måde adskiller Grundtvigs tænkning sig i artiklen 'Moses og Jesus' fra en traditionel luthersk lovforståelse. Loven bliver i en grundtvigsk forståelse nærmest identisk med en skabelseslov. Loven er oplysning om menneskelivets skabelse i Guds billede og om syndefaldet, der delvist har $\varnothing$ delagt ligheden med skaberen. Afgørende er tillige, at denne lov ifølge Grundtvig skal modtages i frihed som livsoplysning. Loven giver i højere grad kundskab om skabelsens sandhed end om menneskelivets manglende sandhed. Aronson udtrykker tankegangen således:

Utmärkande för Grundtvigs lagbegreb är emellertid att det är knutet till skapelsen. 'Sanningen' driver människan, inte direkte in i evangeliet, utan djupare in i hennes mänsklighet. Den viktigaste faktorn i det mänskliga är att vara skapad av och till Gud, alltså att vara av sanning. Det är upplevelsen av sanningen om det mänskliga som för en människa till Kristus. Evangeliet kommer således till en människa via skapelsen (...) Omvändelsen till tro sker därigenom att människan inser sanningen och vänder sig bort från lögnen. ${ }^{87}$

Også Aronson må således rette indvendinger mod Prenters Grundtvigtolkning:

Lagen är hos Grundtvig nära förknippad med livet (...) Tillsammans med den principiella synen på döden medverkar dessa omständigheter till att lagen får en annan karaktär än i paulinskt-luthersk teologi. Dess funktion bliver snarare ett kunskapsmeddelande om det skapade livets villkor än en direkt drivkraft till evangeliet. Det drivande momentet ligger just i själva livsvillkoren, inte i en lagkodex. Därför torde det vara alltför lutherskt uttryckt av Regin Prenter, när han säger: 'Faldets egentlige elendighed er for Grundtvig den, at menneskets forhold til Gud er kommet til at stå i den uopfyldelige lovs tegn' (...) Grundtvigs människosyn ger föga plats för lagens aktivt nedbrytande funktion. Lagens 'andra bruk' är flyttat in i skapelsen och via skapelsen, som i sig sluter starka element av 'lag', kommer människan till sanningen om sig själv. Denna självförståelse är inte primärt tänkt $i$ negativa utan i positiva kategorier. Den sker emellertid mot den mest negativa 
bakgrund människan känner: döden. ${ }^{88}$

Det må mod Prenter fastholdes, at den primære kilde til forståelse for kristendommens tale ikke hos Grundtvig som hos Luther består i samvittighedserfaringen af egen utilstrækkelighed og magtesløshed over for lovens krav. Det er ikke erkendelsen af den "falske menneskelighed", 89 men tværtimod erfaringen af det naturlige menneskelivs sandhed - det vil sige kendskabet til de af Gud opretholdte sande eksistensmuligheder der åbner menneskets $\emptyset$ re for evangeliets sandhed. Netop sammenhængen mellem det menneskelige og det kristelige er en af hovedtankerne hos Grundtvig: evangeliets sandhed forudsætter skabelsens sandhed. Eller formuleret på en anden måde: Guds skabelsesnåde er baggrunden for modtagelsen af Guds genløsende nåde. Således må man med Grundtvig nærmere tale om en skabelseserkendelse end en egentlig accentueret syndserkendelse.

Det betyder imidlertid ikke, at synden og den enkeltes erkendelse heraf slet ingen rolle spiller i Grundtvigs teologi. Hovedsagen for Grundtvig består derimod $i$ at nå frem til en ret forståelse af forholdet mellem skabelsens sandhed og synden. Det er således Grundtvigs pointe, at alvoren i syndens og dødens ødelæggelse kun kan erfares på baggrund af et forudgående og fundamentalt kendskab til skabelsens sandhed og menneskelivets godhed. Syndserkendelsen beskrives derfor af Grundtvig som en sorg over tabet af det skabte livs godhed. "Ingen har Guld-Taarer fældet / Som ei Glimt af Guldet saae." "Skabelsens sandhed og syndens nedbrydelse forholder sig således ikke til hinanden som ligeværdige størrelser. Det væsentligste og mest fundamentale træk ved tilværelsen er skabelsens sandhed - med et fortættet udtryk: livet. Synden og døden eksisterer kun som nedbrydelse af det skabte liv - som fordærvsmagt, der hindrer livets vækst. Livet er den egentlige eksistensform - synden og døden den uegentlige.

Det spørgsmål kan rejses, om der ikke i Luthers teologi, på trods af den åbenlyse fremhævelse af syndserkendelsen som forudsætningen for modtagelse af evangeliet, findes en lignende forståelse af forholdet mellem skabelsen og synden. Også Luther understreger vel skabelsens forrang frem for synden, når han skelner mellem det naturlige skabte liv $i$ dets væsen og den skikkelse, som det syndige menneske ved sit misbrug giver dette liv. Det er ikke det naturlige liv i sig selv, der skal forsages, men alene selviskheden, der fordærver det naturlige liv. På den måde må også hos Luther skabelsestanken være det primære og synden det sekundære, det uegentlige. Netop denne forståelse af forholdet mellem 
skabelse, syndefald og genløsning er i særlig grad hos Gustaf Wingren understreget som en sand evangelisk og luthersk tanke. ${ }^{91}$

Har Prenter så alligevel ret i den måde, hvorpå han sammentænker Luther og Grundtvig? Er deres to forskellige udsagn: "lov-evangelium" og "menneske først, kristen så" udtryk for en sammenfaldende tanke om en ret forståelse af forholdet mellem skabelse, syndefald og genløsning? Er der i virkeligheden med disse udtryk kun tale om en nuanceforskel, hvor forskellige sider af samme forhold betones forskelligt? Helt så enkelt forholder det sig nok ikke. Luthers forståelse af den fortsatte skabelse adskiller sig nemlig på afgørende punkter fra Grundtvigs.

Hos Luther tolkes det naturlige liv, fra den konkrete legemlighed til familie- og samfundsforhold, som et udtryk for Guds velsignelse og videreførelse af sit skaberværk. Det naturlige liv er på den måde at betragte som en daglig gave fra skaberen. Den fortsatte skabelse er en måde, hvorpå Gud på trods af menneskets uindskrænkede syndighed kan oprethoide muligheden for en egentlig sameksistens mennesker imellem. I mennesket kommer denne skabelse blandt andet til udtryk som en fornuftsevne, der sætter den enkelte i stand til på det rent verdslige plan at skelne mellem rigtigt og forkert. I kraft af fornuften og den naturlige lov, der som kærlighedsbudet stiller krav om kærlighed og tjeneste for næsten, kan det naturlige menneske på ydre vis gøre godt. En ydre lovoverholdelse er betingelsen for sameksistensens beståen.

Netop tanken om, at den fortsatte skabelse kommer til udtryk som noget ydre, er af afgørende betydning for Luthers tænkning. Skønt der således i kraft af Guds fortsatte velsignelse af det naturlige liv kan tales om menneskelivets godhed, er der dog dermed intet sagt om menneskets indre, om dets sindelag - det vil sige om det egentlige menneskelige. En bestemmelse af det egentlige menneskelige kan ifølge Luther som bekendt kun ske ud fra en betragtning af den enkeltes gudsforhold. Og her kan der kun være tale om et enten-eller. Enten står mennesket ved sin vantro $i$ et falsk gudsforhold og er således alene at betragte som $k ø d$, eller det er i kraft af troen og retfærdigg ørelsen sat i et sandt gudsforhold og kan derfor betegnes som ånd. Denne skarpe skelnen mellem det ikkeretfærdiggjorte menneskes kødelighed og det retfærdiggjorte menneskes åndelighed resulterer $i$, at Luther nødvendigvis må fastholde det naturlige menneskes uformån til andet end synd. Det naturlige menneske er ifølge Luther alene kød. Det betyder, at skønt dette menneske på rent ydre vis kan være redskab for Guds fortsatte velsignelse og skabelse af det naturlige liv, så er der dog i menneskets indre alene tale om synd og hykleri. Det er selviskheden, der ligger bag den ydre "godhed". 
Ved nærmere eftersyn viser det sig imidlertid, at Luther ikke på dette område er entydig. Luther kan således betragte det naturlige familieliv som udtryk for en fortsat velsignelse, der ikke kun er af ydre karakter. Ægteskabet mellem mand og kvinde beskrives som en rest af det velsignede samliv, beata cohabitatio, som eksisterede før syndefaldet. Mellem mand og kvinde er der fortsat mulighed for en gensidig kærlighed, amor mutuus. Hermed har Luther tilkendegivet, at der også i den naturlige eksistens gives mulighed for en indre, det vil sige en oprigtig form for godhed. Gennem ægteskabet er en rest af skabelsens oprindelige lykke, felicitas, bevaret. Alt sammen er det at betragte som en gave, donum, fra Gud. I Genesis-foreloesningen beskriver Luther det naturlige samliv i familien som en Guds velsignelse, der gør det muligt at udholde tilværelsens mange prøvelser. ${ }^{92}$ Også Luther kan således tillægge det naturlige familieliv, huslivet, opløftende og oplivende egenskaber egenskaber, som forudsætter oprigtighed.

Modsigelsen i Luthers tænkning mellem på den ene side fastholdelsen af en kun ydre, det vil sige en hyklerisk, mulighed for godhed og på den anden side talen om en også indre, det vil sige oprigtig form for godhed, synes ikke at kunne ophæves. Skal talen om den indre godhed, f.eks. muligheden for kærlighed, fastholdes, så kan Luthers skarpe skelnen mellem det naturlige, vantro menneskes kødelighed og det retfærdiggjorte menneskes åndelighed ikke opretholdes. Med forestillingen om kærlighedens mulighed hos det naturlige menneske må påstanden om uforeneligheden mellem $k \varnothing d$ og ånd, mellem syndighed og oprigtig godhed falde. Det naturlige menneske må fra sit eget -- såvel ydre som indre - liv have kendskab til både syndens og godhedens eksistensmulighed.

Der kan ikke herske tvivl om, at det er tanken om uforeneligheden mellem kød og ånd, der bestemmer hele Luthers teologi og hans opg $\varnothing r$ med sin tids romersk-katolske teologi. Den totale syndighed må fastholdes for menneskets egen frelses skyld. Det synes således nærmest uundgåeligt ikke at betragte Luthers syn på det naturlige menneske som udpræget pessimistisk. Flere forskere har dog afvist en sådan tanke om pessimisme i det lutherske menneskesyn, blandt andre Regin Prenter, Bengt Hägglund og Leif Grane. De argumenterer imod pessimismen ved en henvisning til Luthers skelnen mellem mennesket over for Gud, coram Deo, og mennesket over for dets medmennesker, coram huminibus. Hägglund skriver om pessimismen:

Men om man med pessimism i dette sammanhang menar ett 
bortseende från människans naturliga godhet eller hennes möjligheter till det goda, har man ej träffat den lutherska åskådningen utan en förytligad misstolkning därav. Utsagan - eller riktigare bekännelsen -, att människan är en syndare, avser självbedömningen inför Guds ansikte (...) Den motsäger därfor ingalunda uppskattningen av det naturligt goda, som i ulika former möter hos medmänniskorna. ${ }^{93}$

Hägglund understreger, at Luther ved at skelne mellem mennesket over for Gud og over for sine medmennesker har bevaret muligheden for både at tale om den totale syndighed og godheden. Den totale syndighed gælder over for Gud, og godheden gælder kun over for mennesker. For at nå en ret forståelse af Luthers teologi er det således af afgørende betydning at komme til klarhed over, hvad der ligger bag hans skelnen mellem mennesket over for Gud og mennesket over for dets medmennesker. Udtrykket er et af flere, som Luther bruger til at beskrive menneskets situation. Således kan Luther skelne mellem de ting, der ligger over mennesket, res superior, og de ting er ligger under mennesket, res inferior. Der skelnes mellem det, der angår menneskets gudsforhold og det, der angår dets rent verdslige tilværelse. Det siger sig selv, at der ikke kan skelnes fuldstændig imellem de to forhold - det er dog det samme menneske, der indgår i begge forhold. Det er Luther klar over, og derfor bruger han tillige sondringen mellem det indre og ydre menneske, en skelnen, der skal tydeliggøre det enkelte menneskes situation. Når Luther henviser til menneskets indre, mener han dets hjerte og dets sindelag - og det er hovedsagelig den side af mennesket, Luther tænker på, når han bruger udtrykket coram Deo. Menneskets ydre henviser ifølge Luther derimod primært til de forhold, mennesket indgår i, som ikke er direkte berørt af dets sindelag. Luther tænker hovedsageligt her på menneskets handlinger isoleret fra det motiv, der ligger bag dem. Det er denne forståelse, der er baggrunden for udtrykket coram hominibus.

Det bliver således klart, at Luther, når han taler om mennesket coram Deo, mener menneskets inderste - det vil sige mennesket fundamentalt set, det sandt menneskelige, det egentlige menneskelige. Det må derfor konkluderes, at når Luther taler om menneskets totale syndighed over for Gud og om godheden over for mennesker, så menes der en synd og en selviskhed, der gennemsyrer hele menneskets sindelag og indre - det egentlige menneskelige er fuldstændigt $\varnothing$ delagt af synd. Godheden kan således kun forstås som en ydre godhed, der ikke har forbindelse til menneskets inderste. Den er de rammer, hvormed Gud via sin fortsatte skabelse sikrer menneskelivets beståen. Godheden må derfor betegnes 
som menneskelivets godhed og ikke som menneskets godhed. Det er derfor misvisende, når Hägglund i sin kritik af den Luther-tolkning, der understreger pessimismen, taler om "människans naturliga godhet" (jf. note 93). Mennesket har ikke nogen naturlig godhed ifølge Luther. Det har mulighed for på ydre vis at gøre godt, det vil sige at tjene til menneskelivets beståen. Synden betyder derimod, at denne evne til i det ydre at gøre godt i virkeligheden er et udtryk for hykleri og bedrag menneskets indre står i modstrid med dets ydre handling. Der må skelnes mellem muligheden for egentlig godhed og muligheden for at gøre godt.

Også hos Grane afvises tanken om, at Luthers teologi skulle være udtryk for et pessimistisk menneskesyn. Grane understreger, at Luthers arvesyndslære ikke blot skal forstås som en skærpelse af samtidens syn på arvesynden. Luthers bestemmelse af arvesynden er ikke blot et udtryk for en mere dyster forståelse af menneskets egenskaber, men den skal derimod ses "som en afvisning af det synspunkt, hvorunder det får interesse at fremhæve menneskets naturlige godhed eller retfærdighed." 94 Det er ifølge Grane denne sag - det vil sige afvisningen af menneskets naturlige evner i frelsesspørgsmålet - og ikke kritikken af det menneskelige i sig selv, der har Luthers interesse. Heri kan man kun give Grane ret. Det er kampen for Guds alenevirken i frelsesspørgsmålet, der er nerven i Luthers teologi. Kun således kan menneskets tillid til forjættelsen om retfærdigg ørelse og salighed bestå. Imod Grane må det dog indvendes, at denne bestemmelse af Luthers interesse og hensigt ikke forhindrer hans menneskesyn i at være pessimistisk. Man kan derimod hævde, at Luthers pessimistiske menneskesyn er en konsekvens af hans retfærdiggørelseslære.

Det er allerede blevet anskueliggjort, hvordan Luthers tænkning er bygget op omkring et enten-eller. Enten er mennesket fuldstændig syndigt, eller det er fuldstændig retfærdigt - der findes ingen middelvej. Luther siger: "hos Gud bliver der ikke en mellemting tilbage midt imellem retfærdighed og synd." ${ }^{\text {" }}$ Enten er mennesket alene at betegne som kød, eller det er at betegne som ånd. Grane skriver: "kampen mellem kød og ånd er absolut." ${ }^{\circ 6}$ Enten kan mennesket ved sin frie vilje retfærdigg øre sig selv, eller det er på grund af sin trælbundne vilje alene henvist til Guds tilregnende retfærdighed. Alle disse udsagn er ifølge Luther i virkeligheden udtryk for det samme forhold: nemlig den kendsgerning, at der på ingen måde findes noget i mennesket, som kan bidrage til dets frelse. Heraf drager Luther den slutning, at det naturlige menneske fuldstændig er berøvet muligheden for egentlig godhed. At tillægge mennesket en sådan mulighed, ville ifølge Luther nemlig være 
ensbetydende med at tilskrive mennesket, hvad der tilkommer Gud. ${ }^{97}$ Nåden ville være overflødiggjort.

Om Luthers menneskesyn er pessimistisk, afhænger således af, hvordan man forstår pessimisme. Hos Hägglund og Grane afvises tanken om pessimisme ved en henvisning til de ydre rammer, der g $\emptyset \mathrm{r}$ en menneskelig sameksistens mulig - på trods af at mennesket bag de ydre handlinger bestemmes som fuldstændig fordærvet, bundet til synd og selviskhed, og hvor menneskets ydre eksistens derfor bliver et udtryk for hykleri og løgnagtighed. Om det er berettiget at forkaste tanken om pessimisme på den baggrund, kan diskuteres. Det synes dog mere passende at tale om et vist lyssyn i betragtningen af menneskelivet, mens pessimismen i forståelsen af det naturlige menneske må fastholdes.

Herimod vil sandsynligvis både Prenter og Grane rette indvendinger. Det skyldes, at de begge forstår Luthers udsagn om mennesket over for Gud på en helt speciel måde. Prenter skriver: "Luther kan også tale om [menneske-] naturens korruption; men han tænker da ikke på menneskenaturen i og for sig, men på mennesket over for Gud." ${ }^{98}$ Hos Grane bliver tankegangen endnu tydeligere, når han påpeger, at bestemmelsen af mennesket som synder og som fordærvet ikke skal forstås som "en almen, objektiv beskrivelse", ${ }^{99}$ men kun gælder over for Gud. Med en sådan bestemmelse har både Prenter og Grane afvist at tale om det egentlige menneskelige. De ser altså i denne sammenhæng begge bort fra Luthers skelnen mellem det indre og det ydre menneske. Ifølge denne tankegang kan end ikke beskrivelsen af det indre menneske danne baggrund for en bestemmelse af menneskets sande natur. Men kan da overhovedet noget siges om menneskets væsen? Prenter og Grane vil med stor sandsynlighed svare: ikke uafhængigt af menneskets gudsforhold. Og i denne betragtning har de ret - Luther ser altid på mennesket ud fra dets forhold til Gud. Men det er dog ikke ensbetydende med, at man helt må afvise at tale om noget egentligt menneskeligt eller om menneskets sande væsen. Luthers egen tale om mennesket coram Deo bekræfter en sådan antagelse. I De servo arbitrio skelner Luther mellem menneskets situation over for medmennesket og over for Gud. ${ }^{100}$ Beskrivelsen af menneskets situation over for Gud tydeliggør Luther ved hjælp af det latinske adverbium vere, som på dansk betyder "med sandhed" eller "i sandhed". Adverbiet kommer af adjektivet verus, som betyder sand, faktisk eller virkelig. Luthers udsagn: "sed coram Deo vere (...)" kan derfor oversættes: "men over for Gud, i virkeligheden (...)." Med denne formulering har Luther tydeliggjort, at beskrivelsen af mennesket over for Gud er en beskrivelse af menneskets virkelige natur. Det må derfor imod Prenter og 
Grane fastholdes, at Luther med sit udtryk coram Deo, forbundet med sin beskrivelse af det indre menneske, siger noget afgørende om "menneskenaturen i og for sig" - om det egentlige menneskelige.

Det er netop tanken om menneskets indre tillige med hele tanken om et enten-eller i Luthers teologi, der tvinger ham til hovedsageligt at tale om det naturlige menneskeliv som en negativ forudsætning for evangeliet. I Genesis-forelæsningen udtrykker Luther denne tanke ved at tale om tabet af gudbilledligheden. Eftersom gudbilledligheden er fuldstændig tabt, har mennesket ingen erfaring for den eksistens, som er givet med skabelsen i Guds billede: "Når vi derfor taler om gudsbilledet, taler vi om noget ukendt. Ikke nok med at vi ingen erfaring har for det, vi erfarer altid det modsatte." ${ }^{101}$ Fra sit eget liv har det naturlige menneske intet kendskab til skabelsens sandhed - det oplever kun det modsatte: fordærvet og synden. Om tabet af gudbilledligheden og de dermed tilhørende eksistensmuligheder skriver Luther endvidere:

Alt det har vi på grund af synden mistet i en sådan grad, at vi kun kan forstå dem på negativ måde og ikke på positiv måde. Fra det onde, som vi har hos os, må vi slutte os til, hvor stort det gode var, som vi har mistet. ${ }^{102}$

Negativiteten har på den måde forrang frem for positiviteten. Det er den samme side af Luthers tænkning, Grane fremhæver, når han henviser til den lutherske forestilling om, at Guds magt, visdom, godhed, retfærdighed og barmhjertighed "er noget helt andet, end vi ud fra vor erfaring kan forestille os". ${ }^{103}$ Da mennesket er en løgner, har det ingen erfaring af sandhed. Evangeliets tale kan mennesket derfor kun forstå som en modsigelse af dets eget naturlige liv.

Skønt man derfor i luthersk tænkning kan tale om skabelsens forrang frem for synden, idet synden betragtes som nedbrydelse og ødelæggelse af skabelsen, og idet der skelnes mellem skabelsens væsen og den skikkelse, som mennesket $i$ kraft af dets syndighed giver det skabte liv, så gives der dog ikke i luthersk teologi nogen mulighed for en erfaringsmæssig erkendelse af skabelsens sandhed og af dens forrang frem for synden. Skabelsens sandhed når aldrig i de menneskelige sammenhænge til en egentlig og virkelig udfoldelse. Den er jo til enhver tid perverteret af selviskhedens skikkelse. På den måde kan man derfor $\mathrm{i}$ Luthers teologi tale om syndens og negativitetens forrang frem for skabelsens sandhed. Mennesket kender ikke fra sit eget naturlige liv til skabelsens positive fænomener - det kender kun hykleriet.

Heroverfor kunne man indvende, at det skabte menneske dog ifølge 
Luther har erfaring af en naturlig lov - en lov, der sætter mennesket i stand til at erkende kravet om kærlighed og tjeneste for næsten og giver det mulighed for en $y d r e$ efterlevelse af kravet. Igen er det Luthers skelnen mellem det indre og det ydre menneske, der gør sig gældende. I forestillingen om den naturlige lov synes denne skelnen dog at give visse problemer. Erkendelsen af lex naturalis betyder ifølge Luther, at det naturlige menneske i det ydre kan gøre godt samtidig med, at dets indre alene er at betegne som kød - som syndigt. Men hvis lex naturalis betyder, at mennesket kun kan gøre godt i det ydre, hvordan kan denne naturlige evne så sidestilles med kærlighedsloven, der fordrer et sandt indre motiv? En blot ydre tjeneste for næsten er dog ikke det samme som kravet om egentlig kærlighed til medmennesket. Vil man heroverfor hævde, at det naturlige menneske i kraft af lex naturalis kender til kravet om kærlighed, men dog kun kan efterleve det på rent ydre vis - det vil sige som en tjeneste uden egentlig kærlighed, må det (grundtvigske) spørgsmål stilles: hvordan skulle det naturlige menneske fra sit eget kærlighedsløse liv forstå kravet om kærlighed? Skulle det være muligt at erkende kærlighedens krav, hvis man aldrig har haft menneskelige erfaringer af kærlighedsfølelsen? Det forekommer ikke sandsynligt. Heller ikke forestillingen om lex naturalis giver i Luthers teologi plads til en naturlig positiv erfaring for skabelsens sandhed. Prenters sammentænkning af Luthers tanke om "lov-evangelium" og Grundtvigs forestilling om "menneske først, kristen så" må derfor afvises.

Det er afgørende at bemærke sig, at det er selve nerven i Luthers teologi, nemlig hans konsekvent gennemførte skelnen mellem vantroens og troens menneske - mellem det menneske, som alene er bundet til syndens mulighed, og det menneske, der tillige har fået muligheden for egentlig godhed givet - der på forskellige måder tvinger Luther ud $\mathrm{i}$ modsigelser og problemer. Det er denne skelnen, der blandt andet fører til, at Luther principielt må afvise det skabte menneskes mulighed for naturlig kærlighed - også den kærlighed, der kommer til udtryk mellem ægtefæller og mellem forældre og børn. I De servo arbitrio afviser Luther således enhver tanke om en naturlig kærlighed eller godhed selv blandt ægtefæller. Det fremgår klart af sammenhængen i teksten, at hvad Luther i særlig grad langer ud efter, er den almenmenneskelige dydsforståelse og Erasmus' brug af denne i sin kristendomsforståelse. Det bortforklarer imidlertid ikke, at Luther i denne sammenhæng fuldstændig afviser muligheden for en naturlig kærlighed. Al naturlig godhed bliver i den lutherske forståelse et udtryk for hykleri og menneskelig selviskhed. Hele menneskets fordærvelse må fastholdes. ${ }^{104}$ Luthers udsagn om ægteskabet 
og om huslivet samt hans betragtninger om den naturlige lov som en parallel til kærlighedsloven viser dog, at han ikke selv kan opretholde en sådan skarp skelnen - og dermed er han endt i en modsigelse. Problemet $\mathrm{i}$ Luthers tænkning viser sig også i opgøret med Erasmus. Luther understreger med stor styrke imod Erasmus, at det ikke-retfærdiggjorte menneske alene er kød - det vil sige fuldstændig blottet for ånd og for den oprigtige godheds mulighed. Retfærdighed og godhed kan ifølge Luther kun skyldes Guds ånds virke - og delagtighed i denne ånd har kun det kristne menneske. Således drives Luther ud i en modsigelse, når han skal forklare skriftens beretning om hedningen Cornelius' retfærdighed og gudsfrygt: da godheden aldrig kan være menneskets egen præstation, må Cornelius - skønt ikke-kristen - ifølge Luther være af ånd. Men dermed er Luthers skarpe. skelnen mellem det naturlige menneskes kødelighed og det kristne menneskes åndelighed problematiseret. Kampen mellem kød og ånd kan i så tilfælde ikke være absolut. Også det naturlige menneske må til en vis grad være af ånd. Skulle Luthers tanke være den, at en sådan åndsbestemmelse alene gælder skriftens skikkelser, kan en kritik heraf fremføres ved at henvise til Grundtvig. I Den Christelige Bornelaerdom tager Grundtvig skarpt afstand fra en sådan forståelse. Grundtvig anfører, at det er teologisk uholdbart at påstå, "at hos det gamle Menneske er Guds-Billedet aldeles udslettet, og alt virkelig Godt udryddet" ${ }^{\prime 05}$ og samtidig fastholde at skriftens skikkelser som Abraham, Moses, David osv. er undtaget “denne Ford $\varnothing$ mmelses-Dom”. ${ }^{106}$ Grundtvig skriver:

man har dog aldeles overset, at det slet ikke gaaer an at undtage en eneste af den gamle Adams naturlige Børn fra den Dom, man fælder over ham og hele hans Slægt, fælder over den faldne Menneske-Natur, og at man lige saa lidt kan sætte det ny Menneskes Fødsel foran Barnets i Bethlehem, uden at giøre hele Christi Evangelium til Løgn og Fabel. ${ }^{107}$

Grundtvig fremfører denne kritik i en sammenhæng, hvor han udfolder sin centrale forståelse af, at en rest af menneskets gudbilledlighed må være bevaret i form af oprindelig godhed og herlighed og i form af tro, håb og kærlighed. Sammenhængen mellem det naturlige og det kristne menneske må fastholdes, hvis genløsningen skal være mulig. Mens Luther forstår Guds fortsatte skabelse og godheden som noget ydre, der ikke berører det egentlige menneskelige - det vil sige menneskets indre, så er forestillingen om Guds skabelsesnåde hos Grundtvig knyttet til det egentlige menneskelige, menneskets indre. Det må derfor understreges, at 
Grundtvigs kritik ikke kun rammer den lutherske ortodoksi, den rammer derimod selve nerven i Luthers tænkning, nemlig forestillingen om, at det naturlige menneske alene er $k \emptyset \mathrm{d}$ og uden en rest af skabelsens oprindelige godhed og herlighed. Det er her den væsentligste uoverensstemmelse mellem Luther og Grundtvig findes.

Spørgsmålet må stilles, hvad en sådan uoverensstemmelse betyder for forholdet mellem Luther og Grundtvig? Er Grundtvigs tanke om en menneskelig godhed uforenelig med Luthers retfærdiggørelseslære? Er forestillingen om godhed ensbetydende med, at mennesket skal bidrage til sin egen frelse - det var jo netop Luthers indvending mod Erasmus? For at komme til en ret forståelse af Grundtvigs teologi er det afgørende at gøre sig klart, på hvilken måde han taler om godhed og om kærlighed. Disse egenskaber bliver aldrig i Grundtvigs tænkning udtryk for en menneskelig præstation. Som levn af gudbilledligheden er de derimod et udtryk for Guds skabelsesnåde. De er Guds værk i os. Kærligheden mennesker imellem er et udtryk for, at Guds ånd er nærværende - på trods af synden. Også det naturlige menneske er af ånd.

I en vis forstand kan Grundtvig derfor tilslutte sig Luthers udsagn, når han imod Erasmus indvender: "så længe Gud ikke bor i os med sin bistands virke, er alt, hvad vi gør, ondt." ${ }^{108}$ Eller når Luther siger: "Sandelig, hvad Guds nåde ikke skaber, er ikke godt."109 Ligesom Luther vil Grundtvig hævde, at mennesket aldrig af sig selv kan gøre noget godt. I sig selv er mennesket intet. Uden Guds bistand har det ingen mulighed for godhed. Prenter har således ret i at understrege, at Grundtvigs tanke om gudbilledligheden ikke skal forstås som "en religiøs-moralsk potens, som selv kan udfolde sig og dermed nærme sig Gud", ${ }^{110}$ men at den "er den forudsætning, som Gud i sin skabergerning selv sætter ind og opholder for sin genløsergerning"."' Da godheden ifølge Grundtvig aldrig er et udtryk for en menneskelig præstation, men er at betragte som Guds værk - et resultat af Guds skabelsesnåde - kan Grundtvigs teologi forenes med Luthers tanke om Guds alenevirken i frelsen. Godheden betyder ikke, at mennesket kan påberåbe sig nogen fortjeneste eller bidrage til sin egen frelse - både godheden og frelsen er et udtryk for Guds nåde.

Når dette er sagt, må det dog fastholdes, at Grundtvigs tænkning alligevel adskiller sig væsentligt fra Luthers. Grundtvig understreger igen og igen, at Guds nådige bistand til godhed findes allerede i det naturlige menneske. Der må tales om nåde på to måder, nemlig som skabelsens nåde og som genløsningens nåde. I kraft af tanken om skabelses nåde $\mathrm{og}$ den bevarede gudbilledlighed kan Grundtvig således på en helt 
anderledes måde end Luther give en positiv bestemmelse af det naturlige menneske.

Det er værd at bemærke sig, at Grundtvigs interesse således i en vis grad kan sidestilles med Erasmus'. Begge vil de over for Luther fastholde muligheden for at tale om menneskets iboende godhed. Den afgørende forskel mellem Grundtvig og Erasmus er måden, hvorpå de bestemmer denne godhed. Hos Erasmus bestemmes gudbilledligheden psykologisk, og derfor henviser han hovedsageligt til fornuften og viljen, når han skal forklare muligheden for godhed. Godheden er i Erasmus tænkning en menneskelig præstation, som bliver forudsætningen for modtagelsen af frelsen. Det er som bekendt en ganske anderledes måde, Grundtvig taler om godheden på - som skabelsens nåde er den i virkeligheden Guds egen godhed. Den er aldrig en menneskelig præstation. Det kan således imod Luther indvendes, at tanken om godhed ikke nødvendigvis er ensbetydende med at tilskrive mennesket, hvad der tilkommer Gud. Godheden og forestillingen om sola fide kan fastholdes på samme tid.

Forskellen mellem Luthers og Grundtvigs kristendomsforståelser kan blandt andet ses af deres forskellige betragtninger over forholdet mellem inkarnationen og godheden. Hos Luther understreges det, at det naturlige menneskes mulighed for godhed må afvises ud fra den betragtning, at var ikke hele mennesket underlagt syndens herredømme, da ville Kristi værk være overflødiggjort. Inkarnationen ville være forgæves. Bekendelsen til Kristi genløsende værk nødvendigg ør tanken om menneskets uformåen til godhed. ${ }^{112}$ Helt anderledes betragter Grundtvig bevarelsen af den oprindelige godhed som selve forudsætningen for Kristi menneskeblivelse. Var der ikke hos mennesket bevaret en lighed med det guddommelige, kunne Kristus ikke blive menneske. Sammenhængen mellem det guddommelige og det menneskelige er betingelsen for inkarnationen. Grundtvig skiver således: “dersom (...) alt Menneskeligt ved Syndefaldet var blevet djævelsk, da kunde Guds Søn ligesaa lidt blevet et virkeligt Menneske, som han kunde blevet en Djævel." 113 Godheden må fastholdes for inkarnationens skyld. Denne forskel mellem Luther og Grundtvig har betydning for deres forståelse af gudbilledligheden. For Grundtvig er således bevarelsen af en gudbilledlig rest selve præmissen for at genløsningen kan ske. Menneskets dobbelte situation må fastholdes: som halvdødt trænger det til oplivelse - som stadig halvt levende har det den nødvendige forudsætning for at kunne genløses og oplives. I direkte modsætning til Grundtvig understreger Luther over for sine skolastiske modstandere, at gudbilledligheden ved syndefaldet må forudsættes at være fuldstændig tabt. Heraf følger Luthers bestemte afvisning af det 
naturlige menneskes mulighed for oprigtig godhed. Forskellen i synet på gudbilledligheden skyldes til dels en afvigende definition og indholdsbestemmelse af Guds-billedet. Mens Luther bestemmer gudbilledligheden som menneskets retmæssige forhold til Gud og derfor ved syndefaldet må insistere på, at gudsforholdet - det vil sige gudbilledligheden - er fuldstændig $\varnothing$ delagt, så kan Grundtvig, ved at definere menneskets lighed med Gud som ordets samt troens, håbets og kærlighedens mulighed, fastholde tanken om en rest af ligheden med skaberen.

Ovenstående Grundtvig-citat antyder tillige, at forskellen i Luthers og Grundtvigs tænkning tildels skyldes, at de tyder dualismen mellem Gud og Djævel forskelligt. Både Luther og Grundtvig understreger som bekendt uforeneligheden mellem Gud og Djævel. Der er hos begge tale om et enten-eller. Forskellen mellem dem består i en divergerende udlægning af dette enten-eller. Hos Luther understreges det, at mennesket altid enten hører til hos Gud eller hos Djævlen. Der findes ingen anden mulighed. Er menneskets gudsforhold ødelagt - hvilket jo er konsekvensen af syndefaldet - så må mennesket nødvendigvis høre til hos Djævlen. Guds billede er blevet udskiftet med Djævlens billede, imago Diaboli. I stedet for at være bundet til Gud er mennesket nu bundet til Djævlen. Hos Grundtvig derimod understreges tanken om uforeneligheden mellem Gud og Djævel på en sådan måde, at mennesket, der er skabt af Gud og har bevaret en rest af hans lighed, aldrig i egentlig forstand kan høre til hos Djævlen. Mennesket er underlagt Djævlens bedrag, og det er delvist i hans vold, men i kampen mellem Gud og Djævel hører det til på Guds side. Guds billede kan aldrig skiftes ud med Djæulens.

Disse forskelle i Luthers og Grundtvigs kristendomsforståelser betyder, at man må tilslutte sig Aronson, når han konkluderer, at der hos Grundtvig findes en større legitimering "av mycket i det mänskliga livet, som i luthersk tradition vanligen betraktats som skuldbelastat". ${ }^{114}$ Aronson forklarer denne positive bestemmelse af det menneskelige med en henvisning til Grundtvigs særlige forestilling om Djævlen som en personlig kosmisk magt. Det er ifølge Aronson forskydningen af det onde fra mennesket selv til en kosmisk magt uden for mennesket, der hos Grundtvig resulterer i et lysere syn på det menneskelige. Aronson har ret $i$, at der er en tendens hos Grundtvig til at tale om Djæulen som den egentlige synder - løgneren. Som allerede illustreret betyder det dog ikke, at Grundtvig fratager mennesket dets ansvar og delagtighed i denne synd. Ligesom Luther understreger Grundtvig syndens alvor. Grundtvigs positive bestemmelse af det menneskelige skyldes derfor ikke primært, 
som Aronson hævder, hans syndsforståelse, men derimod hovedsageligt hans tanke om gudbilledlighedens bevarelse og forestillingen om Guds fortsatte velsignelse af skaberværket. Det er tanken om skabelsens nåde, der muligg $\varnothing r$ legitimeringen af det menneskelige.

Det er allerede blevet påpeget, at denne positive bestemmelse af det menneskelige ikke nødvendigvis fører til en afvisning af den lutherske retfærdiggørelseslære. Heraf kan man dog ikke som Prenter drage den slutning, at Grundtvig ligesom Luther fastholder tanken om viljens trælbundethed. Prenter tolker således gudbilledligheden og godvilligheden som en blot "passiv bekvemhed hos mennesket til at høre Guds ord". ${ }^{115}$ Med denne tanke vil Prenter understrege, at et samarbejde mellem mennesket og Gud i frelsesspørgsmålet er fuldstændig udelukket. Mennesket kan ikke bidrage til sin egen frelse. Gudbilledligheden er derfor, " (...) set fra menneskets side, ikke noget aktivt, ingen ytring af den "frie' vilje i luthersk forstand". ${ }^{116}$ Egentlig er det misvisende at tale om aktivitet og passivitet ud fra en grundtvigsk betragtning. Problemstillingen optager kun Grundtvig i ringe grad. Vil man fastholde talen om aktivitet og passivitet, må det dog understreges, at Grundtvigs tænkning forudsætter forestillingen om en menneskelig aktivitet. Mennesket kan i kraft af kærlighedens og godhedens mulighed på 'aktiv' måde lade skabelsens sandhed være bestemmende for eksistensen. At det i sidste ende er Gud selv, der står bag denne 'aktivitet', og at den derfor ikke er ensbetydende med menneskets bidrag til egen frelse betyder ikke, at man nødvendigvis som Prenter må bestemme gudbilledligheden som blot en passiv mulighed for at høre evangeliet og tillige betragte viljen som trælbunden. Det naturlige menneskes vilje er ikke hos Grundtvig som hos Luther trælbunden til synd og Djævel. Skønt antastet af Djævlen har mennesket ifølge Grundtvig fortsat kærlighedens og godhedens mulighed. Det særlige i Grundtvigs tænkning er netop understregningen af det skabte livs dobbelthed: synden og godheden må fastholdes på samme tid. Og de må fastholdes som egenskaber, der kan komme til virkelig og egentlig udfoldelse allerede i det naturlige liv. På den måde kan der hos Grundtvig tales om aktivitet - samtidig med at tanken om menneskets fortjeneste og bidrag til frelsen afvises.

Også hos Aronson afvises det, at Grundtvigs tænkning skulle være bestemt af tanken om viljens trælbundethed. Han skriver således, at det er

otvivelaktigt att det hos Grundtvig varken kvantitativt eller kvalitativt finns tillräckligt med material till en lära om viljans trälbundenhet, jämförlig med Luthers. Anmärkningsvärt är hur liten kontaktytan 
bliver vid en jämförelse mellan Grundtvig och Luther. Grundtvigs teologi har en struktur så helt bestämd av motsatsen liv-död, att frågor av viss typ inte ger något klart svar. En sådan fråga är den om viljens trälbundenhet. Vad som slår upp emot en från Grundtvigtexterna är däremot ideliga påståenden om viljens frihet. Grundtvig är stor nog teolog att inse faran härmed och han sätter därför en gräns. Odiskutabelt är emellertid att Grundtvig släpper fram det mänskliga i en helt annan utsträckning än Luther när han ser människan coram Deo. Häri röjer Grundtvig mer släktskap med Ireneus än med Luther. Vill man ställa sammen Grundtvig med Ireneus får man de båda inplacerade i en kristen traditionslinje, som, om den konsekvent följes, inte leder till De servo arbitrio. ${ }^{117}$

Det må således konkluderes, at Prenters tolkning af Grundtvig i sin helhed fremstår som alt for luthersk. Det kan vække undren, at Prenter skønt han selv er opmærksom på Grundtvigs tale om det naturlige menneskes positive eksistensmuligheder og tilmed er bevidst om, at disse eksistensmuligheder er et udtryk for Guds nåde - $i$ sin sammenligning af Luther og Grundtvig helt underbetoner denne side af Grundtvigs tænkning til fordel for fremhævelsen af syndstanken. Prenters bestræbelser på at sammentænke Luther og Grundtvig resulterer $i$, at store dele af Grundtvigs særegne tænkning tilsløres. Dermed ikke være sagt, at en sammentænkning mellem de to slet ikke kan finde sted, eller at Grundtvigs tænkning ikke kan betragtes som en videreførelse af væsentlige sider af Luthers teologi. En sand sammentænkning kan dog først ske, når forskellene mellem de to er påpeget. Således er det afgørende at fremhæve, at der i deres betragtninger over det naturlige menneskeliv findes betydelige uoverensstemmelser, som blandt andet betyder, at man ikke umiddelbart kan sætte lighedstegn mellem deres tanker om det skabte liv som forudsætning for evangeliet, mellem deres gudbilledlighedsforståelser og mellem deres tanker om menneskets vilje og eksistensmuligheder. Disse forskelle må fremhæves, før Grundtvigs tænkning kan bestemmes som en fornyet og selvstændig videreførelse af Luthers væsentligste tanke: nemlig forestillingen om Guds alenevirken $\mathrm{i}$ frelsesspørgsmålet.

Netop selvstændigheden må understreges, når en sammentænkning mellem to forskellige tænkere skal foretages. Luther og Grundtvig er to selvstændige tænkere med hver deres baggrund, placeret i hver deres kontekst og i kamp mod hver deres modstandere - forhold, som får betydning for deres tænkning. Som Wingren udtrykker: "Vad man bekänner står 
(...) alltid i ett visst samband med vad omgivningen förnekar." ${ }^{\text {"18 }}$ Mens Luthers teologi således bærer præg af at være et resultat af en lidenskabelig kamp for en ren forkyndelse af 2. trosartikel, er Grundtvigs teologi ofte blevet betragtet som et resultat af kampen for en ret forståelse af 1. trosartikel. Det er rigtigt, at skabelsestanken er nerven i Grundtvigs tænkning. Det må dog understreges, at Grundtvigs tanke om skabelsen altid er nært forbundet med forestillingen om inkarnationen og Ånden. Skabelsen i Guds billede er ifølge Grundtvig ensbetydende med en skabelse i Kristi billede. Inkarnationen er således den egentlige åbenbaring af menneskets lighed med Gud. Derudover er skabelsen hos Grundtvig i udpræget grad forstået som en fortsat skabelse, der omfatter både frelse og genløsning. Således er skabelsestanken og 1. trosartikel hos Grundtvig nært forbundet med 2. trosartikel om frelseren. Karakteristisk for den grundtvigske skabelsesforståelse er endvidere, at det er Ånden, der er midlet til den fortsatte skabelse. Ånden har således afgørende betydning for såvel det naturlige som det genfødte menneskes udvikling. Også 3. trosartikel er altså hos Grundtvig tænkt sammen med bekendelsen til den 1. trosartikel. Når Grundtvig fremhæver skabelsestanken, så er denne altså ikke isoleret fra tanken om inkarnationen, frelsen og Ånden. Det er trosbekendelsen i sin helhed, der er fundamentet for Grundtvigs teologi. Dette aspekt af Grundtvigs teologi er blandt andet fremhævet af T. Jørgensen. Han påpeger således, at det er mere præcist at kalde Grundtvigs teologi for en trinitarisk teologi end for blot en skabelsesteologi. ${ }^{119}$

Hertil kan tilføjes, at ikke blot trosbekendelsen med dens tre led, men også forsagelsen af Djævlen er bestemmende for alle dele af Grundtvigs teologi. Således kan dåbens sakramente med forsagelsen og bekendelsen til den treenige Gud på flere måder betragtes som midtpunktet $\mathrm{i}$ Grundtvigs teologiske tænkning. Det er Grundtvigs styrke, at han har blik for menneskelivets dobbelthed. Kampen mellem liv og død gælder for alle tilværelsens områder. Fastholdelsen af denne dobbelthed betyder, at Grundtvigs menneskesyn fremstår mere nuanceret end Luthers, der med sin skarpe skelnen mellem kød og ånd kun kan bestemme det naturlige menneske negativt. En bestemmelse, som strider imod enhver menneskelig erfaring - hvilket også modsigelsen i Luthers egen tænkning er et vidnesbyrd om. 


\section{Noter}

Regin Prenter, 'Grundtvigs syn på mennesket' i Kirke og Kultur (Oslo, 1948), 217 f.

Regin Prenter, Den kirkelige anskuelse (Udvalg for Konvent og Kirke og Theologi, 1983), 64.

Ibid., $64 \mathrm{ff}$.

4 Op. cit. (note 1), 221.

5 Regin Prenter, Skabelse og genløsning (Gad, København, 1951), 252 ff.

$6 \quad$ Ibid. (Anis, København, 1998), $108 \mathrm{ff}$.

7 Op.cit. (note 5), 259.

8 Ibid., $262 \mathrm{ff}$.

9 Ibid., 263.

10 Op. cit. (note 2), $103 \mathrm{ff}$.

11 Op. cit. (note 5), 282.

12 Ibid., 284.

13 Ibid., 262

14 Ibid., 263

15 Ibid., $275 \mathrm{ff}$

16 Jf. note 11.

17 N. F. S. Grundtvig, Nordens Mythologi (1832) US V, 408

18 N. F. S. Grundtvig, Christenhedens Syvstjerne (Kirkeligt Samfunds Forlag, København, 1955), 'Den nordiske Menighed', strofe 72 og 131.

19 N. F. S. Grundtvig, Den Christelige Børnelardom (København, 1868), 116 f.

20 Ibid., $158 \mathrm{f}$.

21 N. F. S. Grundtvig, Menneske forst og Christen saa, SV III, nr. 156, strofe 7-8.

22 N. F. S. Grundtvig, Mennesket, som kaldes nyt, SV V, nr. 51, strofe 6.

23 Chr. Thodberg (red.), For sammenhoengens skyld (Århus, 1977), 69 ff.

24 Harry Aronson, Mänskligt och kristet (Lund, 1960), 158.

25 Op. cit. (note 18), strofe 52.

26 Ibid., Efterskrift til 'Den nordiske Menighed', strofe 49.

27 Ibid., strofe 24

28 Op. cit. (note 19), $143 \mathrm{f}$.

29 Ibid., 144.

30 Ibid., 298.

31 N. F. S. Grundtvig, Tid og Evighed, SV IV, nr. 285, strofe 10. 
Op. cit. (note 22), strofe 5.

N. F. S. Grundtvig, Selv-Fornagtelsen, SV V, nr. 52, strofe 1.

N. F. S. Grundtvig, 'Folkelighed og Christendom' i Dansk Kirketidende, nr. 107 (1847), US IX (1909), 88.

Op. cit. (note 19), 35.

Ibid., 34.

Op. cit. (note 18), strofe 107. Op. cit. (note 19), 118.

Ibid., $119 \mathrm{f}$.

Ibid., 121.

Ibid., 132, min kursivering.

Ibid., 119.

Ibid., $144 \mathrm{f}$.

Ibid, 145.

Ibid., $147 \mathrm{ff}$.

Ibid., 147.

Op. cit. (note 22), strofe 7.

Op. cit .(note 19), 132, jf. note 41.

Op. cit. (note 22), strofe 6.

Op. cit. (note 17), 402.

Ibid., 402.

Op. cit. (note 19), 36.

Ibid., $119 \mathrm{ff}$.

Ibid., 146.

Op. cit. (note 22), strofe 1.

Op. cit. (note 19), 132, min kursivering.

N. F. S. Grundtvig, Danskeren, nr. 37 (1851), 590.

Ibid., 592.

Op. cit. (note 19), 152.

Ibid., 148.

Ibid., 157.

Ibid., 132.

Op. cit. (note 22), strofe 1.

$O p$. cit. (note 18), strofe 78 , min kursivering.

Op. cit. (note 19), $116 \mathrm{f}$.

Ibid., $149 \mathrm{f}$.

N. F. S. Grundtvig, Danskeren, nr. 38 (1851), 608.

Op. cit. (note 21 ), strofe 1, 3 og 7 .

Op. cit. (note 17), 401. 
72

Op. cit. (note 21), strofe $1 \mathrm{ff}$.

Op. cit. (note 19), 120.

Op. cit. (note 21), strofe 8 .

K. E. Bugge, 'Menneske først - Grundtvig og hedningemissionen' i Grundtvig-Studier (2001), 137.

Ibid., 138.

Ibid., 144.

N. F. S. Grundtvig, 'Moses og Jesus' i Dansk Kirketidende, nr. 44 (1852), 706.

Ibid., 708.

Op. cit. (note 19), $31 \mathrm{ff}$.

Op. cit. (note 76), $709 \mathrm{ff}$.

Ibid., 711.

Ibid., 709.

Ibid., 710 .

Ibid., 713.

Op. cit. (note 19), 125.

Op. cit. (note 21 ), strofe 7.

Op. cit. (note 73), 144.

Op. cit. (note 24), $241 \mathrm{f}$, min kursivering.

Ibid., $232 \mathrm{f}$, min kursivering.

Op. cit. (note 5 eller 7), 262.

Op. cit. (note 18), strofe 71.

Gustaf Wingren, Skapelsen och lagen, $49 \mathrm{ff}$.

WA 42, 149, $12 \mathrm{ff}$.

Bengt Hägglund, De homine - Människouppfatningen $i$ äldre luthersk tradition (Lund, 1959), 105.

Leif Grane, Protest og konsekvens (Gyldendal, 1968), 73.

$W A$ 18, 768, 17 f. "Neque enim apud Deum relinquitur medium inter iustitiam et peccatum"

Op. cit. (note 94), 74.

WA 8, 112, 19

Op. cit. (note 1), 222.

Op. cit. (note 94), 98.

WA $18,744,1$.

$W A$ 42, 47, 31 ff. "Ergo cum de imagine illa loquimur, loquimur de re incognita, quam non solum non sumus experti, sed perpetuo contraria experimur."

$W A$ 42, 126, 20 ff. "Haec omnia per peccatum ita amisimus, ut solum 
privative et non positive ea possimus intelligere. Ex malo enim, quod retinemus, cogimur colligere, quantum bonum sit, quod amisimus."

103 Op. cit. (note 94), 78.

$104 W A 18,742,22 \mathrm{ff}$.

105 Op. cit. (note 19), 146.

106 Ibid., 146.

107 Ibid., 146.

$108 W A 18,634,18 \mathrm{f}$. "dum Deus opere suo in nobis non adest, omnia esse mala quae facimus."

109 WA 18, 636, 4. "Quod vero gratia Dei non facit, bonum non est."

110 Op. cit. (note 2), 64.

111 Ibid., 64.

$112 W A 18,786,17 \mathrm{ff}$.

113 Op. cit. (note 19), 110.

114 Op. cit. (note 24), 109.

115 Op. cit. (note 1), 221.

116 Op. cit. (note 2), 64.

117 Op. cit. (note 24), $223 \mathrm{f}$.

118 Op. cit. (note 91), 14.

119 Theodor Jørgensen, 'Treenighedsteologi og folkelighed' i J. H. Schjørring (red.), Menneske forst, kristen så. Helge Grells Grundtvig-disputats til debat (København, 1988), $18 \mathrm{f}$. 